\title{
Nathanael Jacob Gerlach i Christian Gabriel Fischer w Północnych Niderlandach: zapomniane źródło do dziejów medycyny i przyrodoznawstwa w Zjednoczonych Prowincjach późnych lat 20. XVIII w. - część I
}

\begin{abstract}
Summary
In early modern times, numerous inhabitants of the Polish-Lithuanian Commonwealth, both townsmen and representatives of the nobility and magnatery, visited the United Provinces. Many of the burghers also studied at the University of Leiden or other Dutch universities and gymnasia. In the autumn of 1727, Nathanael Jacob Gerlach from Gdańsk/Danzig matriculated at the Academia Lugduno-Batava. The Danziger, together with his tutor, Christian Gabriel Fischer, took a few-year educational journey through Western countries. The testimony of their several months' stay in the Netherlands is the $2^{\text {nd }}$ volume of Fischer's handwritten Itinerarium. The selection presents those excerpts from the $2^{\text {nd }}$ volume of the diaries which describe people, places and events related to the teaching of medicine and natural history in the $18^{\text {th }}$ century Netherlands. The first part of the paper focuses on Leiden, the second one - on Amsterdam, Haarlem and Utrecht.
\end{abstract}

Słowa kluczowe: historia medycyny, historia anatomii, historia chirurgii, historia naturalna, filozofia przyrody, historia edukacji, Niderlandy XVIII w., Gdańsk, Lejda, Amsterdam, peregrinatio academica 
Keywords: history of medicine, history of anatomy, history of surgery, natural history, philosophy of nature, history of education, the Netherlands in the $18^{\text {th }} \mathrm{c}$., Danzig (Gdańsk), Leiden Amsterdam, peregrinatio academica

W czasach wczesnonowożytnych młodzi podróżnicy pochodzący z Rzeczypospolitej - Korony, Litwy i Prus Królewskich - w trakcie swych podróży edukacyjnych chętnie odwiedzali Niderlandy Północne. Zarówno w XVII, jak i XVIII w. tacy peregrynanci trafiali do Lejdy, Amsterdamu, Harlemu, Hagi, Franeker, Harderwijk oraz innych miast i miasteczek Zjednoczonych Prowincji. Niektórzy z nich - przede wszystkim mieszczanie będący protestantami - immatrykulowali się na jeden lub kilka semestrów na co najmniej jednej niederlandzkiej uczelni ${ }^{1}$ i nierzadko kończyli podjęte tam studia ze stopniem doktora. Dotyczyło to nie tylko przyszłych medyków i teologów kalwińskich, ale także późniejszych architektów czy orientalistów². Inni zwiedzali okolice, podziwiali rozmaite kolekcje, ogrody botaniczne, fortyfikacje i budynki ,architektury cywilnej”, uczyli się fechtunku i obcych języków, nabierając w ten sposób civilité, a więc ogłady. Było to z kolei charakterystyczne dla przedstawicieli szlachty katolickiej oraz ma-

${ }^{1}$ Podziękowania: $\mathrm{W}$ opracowaniu wykorzystano m.in. materiały pozyskane $\mathrm{w}$ trakcie pobytu studyjnego w Universitaire Bibliotheken Leiden w ramach Van de Sande Fellowship. Uczestnicząc $w$ uniwersyteckich zajęciach publicznych oraz kolegiach prywatnych prowadzonych przez profesorów.

2 Zob. np. M. Pawlak, Studia uniwersyteckie młodzieży z Prus Królewskich w XVIXVIII w., Toruń 1988, tab. 25-27, 29 (b.s.); M. Chachaj, Podróże edukacyjne młodzieży $z$ Prus Królewskich do Bolonii, Sieny i Perugii w XVI i XVII wieku, [w:] J. Wijaczka (red.), Prusy Ksiązęce i Prusy Królewskie w XVI-XVIII wieku, Kielce 1997, s. 195-210; M. Pawlak, Studia uniwersyteckie absolwentów Gimnazjum Elbląskiego w latach 15361772, „Zeszyty Naukowe Uniwersytetu Mikołaja Kopernika. Nauki Humanistyczno-Społeczne" 1967, t. 24, s. 112-144; H. Kenkel, Studenten aus Ost- und Westpreußen an außerpreußischen Universitäten vor 1815, anhand der gedruckten Matrikeln, Hamburg 1981; M. Pawlak, Wyjazdy młodzieży warmińskiej na studia uniwersyteckie w XVI-XVIII w., „Komunikaty Mazursko-Warmińskie” 1993, t. 3, s. 403-411; tenże, Studia uniwersyteckie grudziązan w epoce staropolskiej, „Zeszyty Naukowe Wyższej Szkoły Pedagogicznej w Bydgoszczy. Studia Historyczne” 1993, t. 3, s. 59-68; tenże, W. Długokęcki, Studia uniwersyteckie malborczyków do 1773 roku, Torun 2004; B. Siek, A. Szarszewski, Vitae medicorum Gedanensium Ludwiga von Hammena i Valentina Schlieffa, Gdańsk 2015, s. 192-253; B. Nadolski, Wyjazdy młodzieży gdańskiej na studia zagraniczne w XVII w., „Rocznik Gdański” 1965, R. 24, s. 173-215; L. Thijsse, Polska i Niderlandy: 1000 lat kontaktów, Zupthen 2003, passim; K. Pękacka-Falkowska, The Medical Faculty at the University of Leiden and its Graduates from the Polish-Lithuanian Commonwealth. Some Introductory Remarks, „Bulletin der Polnischen Historischen Mission” 2020, nr 15, s. 97-138, DOI: http://dx.doi.org/10.12775/BPMH.2020.004. 
gnaterii ${ }^{3}$, acz trzeba pamiętać, że również dla protestantów ze stanu mieszczańskiego pozainstytucjonalny wymiar ich wojaży edukacyjnych miał charakter podstawowy ${ }^{4}$.

Jednym z najwspanialszych rękopiśmiennych świadectw kilkumiesięcznego pobytu edukacyjnego w Republice Zjednoczonych Prowincji (w I poł. XVIII w.) peregrynanta pochodzącego z dawnej Rzeczypospolitej jest drugi tom dziennika podróży uczonej pewnego dwudziestokilkulatka z Gdańska5 . Nathanael Jacob Gerlach (1706-1778), bo o nim mowa, miał zostać w przyszłości uznanym prawnikiem, uczonym prywatnym i jednym z pierwszych członków Societas Physicae Experimentalis, czyli gdańskiego Towarzystwa Przyrodniczego ${ }^{6}$. Spisana przez jego preceptora Christiana Gabriela Fischera relacja z pobytu w Zjednoczonych Prowincjach - zamknięta w jednym $\mathrm{z}$ dwunastu tomów Itinerarium ich wspólnej podróży uczonej po Europie (tab. 1) - dostarcza licznych informacji z zakresu historii nauki (w tym medycyny, botaniki i kolekcjonerstwa przyrodniczego), edukacji, sztuki, stosunków wyznaniowych, form produkcji, życia codziennego itd. Jest także - ze względu na swoją rozległość i mnogość poruszanych w niej zagadnień - źródem unikatowym, uzupełniającym inne przekazy z epoki.

W połowie listopada 1727 r. po zakończeniu edukacji w Athaeneum Gedanense $^{7}$ dwudziestojednoletni Gerlach, przybrany syn ${ }^{8}$ Jacoba Theodora Kleina - gdańskiego urzędnika, prawnika i naturalisty - razem ze swym opiekunem Christianem Gabrielem Fischerem zatrzymał się w Lejdzie na semestr zimowy. Po zwiedzeniu ziem Rzeszy ${ }^{9}$ - m.in. po dłuższych postojach w Dreźnie, Lipsku, Jenie i Erfurcie

${ }^{3}$ A. Kucharski, Theatrum peregrinandi. Poznawcze aspekty staropolskich podróży w epoce późnego baroku, Torun 2013, passim.

${ }^{4}$ Więcej o nieformalnym wymiarze peregrynacji akademickich $\mathrm{w}$ przypadku studentów medycyny zob. np. K. Pękacka-Falkowska, Matthias Ernst Boretius z Mazur $i$ jego promocja doktorska $w$ Niderlandach: $z$ badań nad historia nauczania medycyny w XVIII wieku, [w:] A. Magowska z zesp. (red.), Wybrane problemy historii medycyny. W kręgu epistemologii i praktyki, Poznań 2020, s. 205-221.

5 Biblioteka Politechniki Gdańskiej (dalej jako BPG), sygn. Ms. D.a.85 (vol. II).

${ }^{6}$ E. Schumann, Geschichte der Naturforschenden Gesellschaft in Danzig 17431892: Festschrift zur Feier des 150 jährigen Bestehens der Naturforschenden Gesellschaft, Danzig 1893, s. 5, 80.

${ }_{7}$ Do gdańskiego gimnazjum akademickiego został immatrykulowany 24 kwietnia 1722 r. i wpisany do secundy. Księga wpisów uczniów Gimnazjum Gdańskiego. 1580 1814., oprac. Z. Nowak, P. Szafran, Warszawa 1974, s. 306.

${ }^{8}$ Ojciec Gerlacha, pochodzący z Torunia Nathanael, medyk, zmarł w Gdańsku w 48. roku życia 8 września $1715 \mathrm{r}$. Matka zmarła przy porodzie.

${ }^{9}$ BPG, sygn. Ms. D.a.85 (vol. I). Transkrypcja pierwszego tomu jest opracowywana przez zespół działający przy Instytucie Kultury Miejskiej i Bibliotece Politechniki Gdańskiej. 
Tabela 1. Zestawienie tytułów poszczególnych tomów relacji i miejsc przechowywania

\begin{tabular}{|c|c|c|}
\hline Tom & Tytuł & $\begin{array}{c}\text { Miejsce } \\
\text { przechowywania }\end{array}$ \\
\hline 1. & $\begin{array}{l}\text { Herrn Nathanael Iacob Gerlachs erste Reise. } \\
\text { aus seiner Vater-Stadt Danzig, durch Cahsu- } \\
\text { ben, Pommern, die Marct Brandenburg, durch } \\
\text { Sachsen, Hessen, durch die Wetterau, über den } \\
\text { RheinStrom bis an die Niederländische Gränt- } \\
\text { zen: nebst denen dabey gesamleten Observatis } \\
\text { PhysicoMathematicis, Oeconomicis, Mechanicis, } \\
\text { Geographicis und Literariis: in einem accuraten } \\
\text { Journal beschrieben und mit einem vollständigen } \\
\text { Register versehen. }\end{array}$ & $\begin{array}{l}\text { Biblioteka Poli- } \\
\text { techniki Gdań- } \\
\text { skiej, sygn. Ms } \\
\text { D.a.85 (vol. I) }\end{array}$ \\
\hline 2. & $\begin{array}{l}\text { Herrn Nathanael Iacob Gerlachs andere Reise. } \\
\text { durch die Vereinigte Niederlande bis nach Engel- } \\
\text { land, worinnen begriffen, so wohl eine Nachricht } \\
\text { von der Stadt Leiden und der dortigen Université, } \\
\text { als auch Geographische, Politische, Oeconomi- } \\
\text { sche und curieuse Remarques über verschiedene } \\
\text { andere Örter: mit nöthigen Reisen, auch ange- } \\
\text { wiesenen zulänglichen Beylagen erläutert. }\end{array}$ & $\begin{array}{l}\text { Biblioteka Poli- } \\
\text { techniki Gdań- } \\
\text { skiej, sygn. Ms } \\
\text { D.a.85 (vol. II) }\end{array}$ \\
\hline 3. & $\begin{array}{l}\text { Herrn Nathanael Iacob Gerlachs dritte Reise } \\
\text { nach Engelland Untertitel in einem continuirten } \\
\text { Reise Journal fleißig beschrieben und mit aller- } \\
\text { hand Observationibus Naturalibus Mechanicis, } \\
\text { Oeconomica Politicis auch einigen Literariis, } \\
\text { vom Majo bis Julium 1728. }\end{array}$ & $\begin{array}{l}\text { TU Berlin, sygn. } \\
\text { 2B220 }\end{array}$ \\
\hline 4. & $\begin{array}{l}\text { Hrn: Nathanael Iacob Gerlach: vierte Reise von } \\
\text { Holland durch die spanische österreichische } \\
\text { Niederlande, Braband, Flandern nach Franck- } \\
\text { reich: in einem continuirten Reise Journal fleißig } \\
\text { beschrieben und mit allerhand Observationibus } \\
\text { erläutert. }\end{array}$ & $\begin{array}{l}\text { Biblioteka Poli- } \\
\text { techniki Gdań- } \\
\text { skiej, sygn. Ms } \\
\text { D.a.85 (vol. IV) }\end{array}$ \\
\hline 5. & $\begin{array}{l}\text { Hrn: Nathanael Iacob Gerlach: fünfte Reise: } \\
\text { bestehende in einem Tage-Register deßen was } \\
\text { in Paris diese Winter Monathe über merckürdi- } \\
\text { ges passirt und observiret worden: mit allerhand } \\
\text { Reflectionen erläutert als 1sten Theil deßelben } \\
\text { beschrieben. }\end{array}$ & $\begin{array}{l}\text { Biblioteka Poli- } \\
\text { techniki Gdań- } \\
\text { skiej, sygn. Ms } \\
\text { D.a.85 (vol. V) }\end{array}$ \\
\hline 6. & $\begin{array}{l}\text { Herrn Nathanael Jacob Gerlach sechste Reise } \\
\text { oder des Parisischen TageRegisters, die Sommer- } \\
\text { Monathe über zusammen getragen und mit nöthi- } \\
\text { gen Reflectionen erläutert und beschrieben durch } \\
\text { Christian Gabriel Fischer Theil 2, vom 13. April } \\
1729 \text { bis den 25. Aug. }\end{array}$ & $\begin{array}{l}\text { SU Bremen, sygn. } \\
\text { bd } 4426-2\end{array}$ \\
\hline
\end{tabular}




\begin{tabular}{|c|c|c|}
\hline 7. & $\begin{array}{l}\text { Hrn. Nathanael Jacob Gerlach Siebende Reise } \\
\text { von Paris durch Orleans, Namtes, Bourdeaux, } \\
\text { Toulouse, Toulon und Marseille über die See bis } \\
\text { Genuoa, mit allerhand Anmerckungen beschrie- } \\
\text { ben durch Christian Gabriel Fischer. vom 27. Aug. } \\
1729 \text { bis den 25. Nov. }\end{array}$ & $\begin{array}{l}\text { Właściciel pry- } \\
\text { watny https:// } \\
\text { www.antiquariat. } \\
\text { de/angebote/GID } \\
\text { 26759197.html }\end{array}$ \\
\hline 8. & $\begin{array}{l}\text { Hrn: Nathanael Iacob Gerlach: achte Reise oder } \\
\text { achtes Journal deßen was in Genua, Piacenza, } \\
\text { Parma, Reggio, Modena, Bologna, Florentz, Pisa, } \\
\text { Livorno ind Siena bis Rom passiert: mit nötigen } \\
\text { Remarqven beschrieben. }\end{array}$ & $\begin{array}{l}\text { Biblioteka Poli- } \\
\text { techniki Gdań- } \\
\text { skiej, sygn. Ms } \\
\text { D.a.85 (vol. VIII) }\end{array}$ \\
\hline 9. & $\begin{array}{l}\text { Herrn Nathanael Iacob Gerlach neunte Reise } \\
\text { bestehende in } 2 \text { Büchern. deren erstes von beson- } \\
\text { dern Begebenheiten in Rom und der gewöhnligen } \\
\text { Excursion nach Neapel: das zweÿte aber von } \\
\text { Merckwürdigkeiten der Stadt Rom handelt. }\end{array}$ & $\begin{array}{l}\text { Biblioteka Poli- } \\
\text { techniki Gdań- } \\
\text { skiej, sygn. Ms } \\
\text { D.a.85 (vol. IX) }\end{array}$ \\
\hline 10. & $\begin{array}{l}\text { Herrn Nathanael Iacob Gerlach zehende Reise. } \\
\text { von Rom nach Loretto, Venedig, Padua, Verona, } \\
\text { Meiland, Turin, Chambery, Lyon und Gent. }\end{array}$ & $\begin{array}{l}\text { Biblioteka Poli- } \\
\text { techniki Gdań- } \\
\text { skiej, sygn. Ms } \\
\text { D.a.85 (vol. X) }\end{array}$ \\
\hline 11. & Brak danych & Brak danych \\
\hline 12. & $\begin{array}{l}\text { Herrn Nathanael Iacob Gerlach zwölffte Reise } \\
\text { durch die mehresten Kreise Teutschlandes. in } \\
\text { einem beständigen Tage Register beschrieben } \\
\text { und mit allerhand Anmerckungen erlaütert: die- } \\
\text { sen sind vorgesetzet einige Notæe zu Hrn. Kuchel- } \\
\text { beckers allerneüeste Relation vom Röm: Kaÿserl: } \\
\text { Hoffe. }\end{array}$ & $\begin{array}{l}\text { Biblioteka Poli- } \\
\text { techniki Gdań- } \\
\text { skiej, sygn. Ms } \\
\text { D.a.85 (vol. XII) }\end{array}$ \\
\hline
\end{tabular}

- podróżnicy ruszyli w drogę do Zjednoczonych Prowincji. Po krótkim pobycie w Utrechcie (7-13 listopada) ${ }^{10}$ wjechali do Lejdy, gdzie zamieszkali na Langebrug $\mathrm{w}$ należącycym do Heinricha Koorinka domu zwanym Templum Salomonis ${ }^{11}$. Gerlach 15 listopada zapisał się na wydział prawa Academia Lugduno-Batava ${ }^{12}$. W trakcie kolej-

10 Tamże, $\$ 282-300$.

${ }^{11}$ BPG, sygn. Ms. D.a.85 (vol. II), Einleitung. Mianem Templum Salomonis określano w Lejdzie także budynek na Nieuwsteeg, w którym znajdowała się onegdaj drukarnia Guyotów. Zob. P. Hoftijzer, Pallas Nostra Salus. Early modern Printer's Marks in Leiden as Expression of Professional and Personal Identity, [w:] A. Wolkenhauer, B.F. Scholz (red.), Typographorum Emblemata: The Printer's Mark in the Context of Early Modern Culture, Berlin 2018, s. 179.

${ }^{12}$ BPG, sygn. Ms. D.a.85 (vol. I), \$. 296; W.N. Du Rieu (red.), Album studiosorum Academiae Lugduno Batavae 1575-1875, Apud Martinum Nijhoff 1875, s. 914. W Ordo Lectionum Atumnalium et Hibernarum z 1727 r. podano następujący plan zajęć z medy- 
nych miesięcy zajmowały go także, jak zanotował jego opiekun, filozofia i matematyka oraz praktyczna nauka języków obcych, zwłaszcza francuskiego ${ }^{13}$ oraz angielskiego ${ }^{14}$. Preceptor młodzieńca oddawał się $\mathrm{w}$ tym czasie - niekiedy sam, niekiedy z podopiecznym - poznawaniu miasta oraz okolicy. Między innymi uczestniczył w wykładach i pokazach publicznych oraz prywatnych; wizytował uczonych w ich laboratoriach i kamienicach; zwiedzał drukarnie, biblioteki, ogrody i liczne muzea. Brał również udział $\mathrm{w}$ aukcjach, zwłaszcza naturaliów, podczas których nabywał rzadkie obiekty dla dworu drezdeńskiego oraz swego mocodawcy z Gdańska ${ }^{15}$. Wszystko to - i wiele więcej - opisywał następnie w dzienniku podróży, do niektórych z opisów dołączając ilustracje oraz uproszczone szkice.

Co może dziwić współczesnego czytelnika, autorem dziennika studenckiej podróży Gerlacha nie był uczeń, tylko jego opiekun, profesor Fischer. Trzeba jednak pamiętać, że w czasach wczesnonowożytnych Reisebücher $\mathrm{z}$ wojaży edukacyjnych spisywali zarówno peregrynanci ${ }^{16}$,

cyny, chymiatrii, fizyki i prawa, w których to zajęciach mogli uczestniczyć albo uczestniczyli Gerlach i Fischer: „Mane. Hora septima. D. Hermannus Boerhaave tempore verno et aestivo Stirpes in Horto demonstrat hora septima. Hyeme Chemica in Laboratorio hora nona. / Hora nona. (...) S. Iohannes Iacobus Vitriarius selectas Iuris publici materias explicabit. / Hora decima (...) S. Guil. Iac. 's Gravesande diebus Lunae. Martis et Iovis Cosmographiae principia et usum globorum explicar. Die autem Mercurii, hora undecima, varia circa Physicam experimentis in Theatro Physicam illustrabit (...). / Hora undecima. (...) D. Antonius Schultingus de Rebus, earum iuribus dominiique adquirendi modis secundum ordinem Intitutionum tractabit. Oosterdijk Schacht diebus Lunae et Martis Febrium historiam et curationem explicabit (...). A Meridie. Hora tertia. D. Bernhardus Siegfr. Albinus Barth. Eustachii Tabulas anatomicas illustrabit (...) selectiora Anatomica tractabit. (...) D. Hermannus Boerhaave et D. Hermanus Oosterdijk in Nosocomio publico studiosos Medicinae in morborum dignotione per sua signa, cognitione per suas causas, et curatione per sua indicata exercent, atque sic ad praxin manuducuntr (...)".

${ }^{13}$ BPG, sygn. Ms. D.a.85 (vol. I), §. 295-300.

${ }^{14}$ Aneks, $\$ 34$.

15 Ch. Sendel, XVI. Lobrede auf Herrn Secretaire Jacob Theodor Klein, „Neue Sammlung von Versuchen und Abhandlungen der Naturforschenden Gesellschaft in Danzig“, Bd. 1, Danzig 1778, s. 300-316; BPG, sygn. Ms. D.a.85 (vol. II), §. 20.

${ }^{16}$ Zob. np. Biblioteka Uniwersytetu Wrocławskiego, sygn. R 2829 (dziennik podróży uczonej Philippa Jakoba Sachsa von Löwenheim): Kurtzer Entwurff meiner Reisen so wol i Hich- und Nueder Deutschland, durch das Röm Reich, Vereinigte so wol Span, Niederlanden, wie auch durch Franckreich als Italien vo Ao, 1646 biss 1651; Polska Akademia Nauk Biblioteka Gdańska (dalej jako PAN BG) Ms. 925 i Ms. 925a (dziennik podróży uczonej Georga Schroedera, lata 50. XVII w.): Fragmentum der ReiseBeschreibung G. Schroeders Dantiscani, in Patria Consulis Ao . 1703 d. ... fato functi; PAN BG, Ms. 924 (dziennik podróży uczonej Karla Friedricha Gralatha, lata 60. XVIII w.): Reise-Journal von K.F. Gralath; eigenhaendige Aufzeichnungen ueber seine Studienreise, $1764-1767$. 
jak i ich preceptorowie ${ }^{17}$. W tym drugim przypadku nauczyciele dokumentowali przebieg podróży edukacyjnej podopiecznych na wyraźne życzenie ich opiekunów prawnych, najczęściej rodziców. Ci ostatni, zatrudniając nauczyciela, nierzadko zobowiązywali go bowiem do prowadzenia zarówno regularnej korespondencji, w której informowano by o postępach czynionych przez syna, jak i do spisywania dziennika, który dokumentowałby kolejne etapy finansowanej przez nich peregrinatio academica ${ }^{18}$. Nie dziwi zatem, że w przypadku Itinerarium młodego Gerlacha Fischer bardzo chętnie opisywał także to, co bezpośrednio interesowało Kleina. Doniesienia o rozmaitych kolekcjach przyrodniczych, aukcjach naturaliów, pokojach studyjnych uznanych Gelehrte, ogrodach medycznych i ogrodach prywatnych - wszystko to, obok informacji zawartych w osobnych listach ${ }^{19}$, było skierowane do sławnego gdańszczanina. Wydaje się zresztą, że Fischer sporządzał takie deskrypcje z wielką ochotą; wszak dzielił z gdańskim „przyrodnikiem" intelektualne pasje i upodobania.

Ponieważ o Kleinie pisano w innych miejscach, nie będziemy przytaczać tu jego biogramu ${ }^{20}$. Warto natomiast napisać kilka słów o Fischerze, który w polskiej historiografii jest w zasadzie nieznany. Preceptor Gerlacha pochodził z Królewca. Urodził się 10 sierpnia $1686 \mathrm{r}$. w rodzinie kupieckiej ${ }^{21}$. Od 1703 r. studiował języki orientalne i teo-

${ }^{17}$ Zob. np. PAN BG, Ms. Uph. Fol. 167-170 (dziennik podróży uczonej Samuela Huwaerta spisany przez Fischera): Herrn Samuel Huwaerts aus Dantzig Reise-Tabellen, darinnen In einem bestaendigen Tage Register fleissig angemercket wid 1. Die Zeit und Stunde, wenn Er auf sie Post Stationes ankommen, 2. Wenn Er wieder abgegangen, 3. Wie Er die Haup Orter befunden, 4. Was vor Mittel Orter und Wege Er durchreiset, 5. Was sich vom Unterscheid der Laender anmercken lassen, 6. Wie viel ihm die Extra Posten und die Fuhr Leute, auch die Zehrung auf dem Wege, mit andern zufaelligen Augaben gekostet, eingerichtet und entworffen von Christian Gabriel Fscher aus Koenigsberg Anno 1732.

${ }^{18}$ Zob więcej w: D. Żołądź-Strzelczyk, M.E. Kowalczyk (red.), Źródła do dziejów staropolskich podróży edukacyjnych, Wrocław 2018.

${ }_{19}$ Wielokrotnie w dziennikach Fischer podawał, że pozostałe informacje na dany temat zostały przesłane do Kleina w osobnych listach lub zapisane w książkach, które opiekun zabrał ze sobą w podróż uczoną z młodym podopiecznym (albo kupił w trakcie tej podróży).

${ }^{20}$ Zob. np. P. Paluchowski, Jacob Theodor Klein, https://www.gedanopedia.pl/gdansk/?title=KLEIN_JACOB_THEODOR [dostęp: 1.02.2020]; S. Brzozowski, Jacob Theodor Klein, https://www.ipsb.nina.gov.pl/a/biografia/jakub-teodor-klein?print; geneologia rodziny zob. D. Weichbrodt geb. v. Tiedemann, Patrizier, Bürger, Einwohner der Freien und Hansestadt Danzig: in Stamm- und Namenstafeln vom 14.-18. Jahrhundert, Klausdorf/Schwentine Rosenberg [1988], Bd. 1, bs.: III. Tafel: Klein (Kleen).

${ }^{21}$ Biogram zrekonstruowano na podstawie: C. von Prantl, Fischer, Christian Gabriel, [w:] Allgemeine Deutsche Biographie, hrsg. von der Historischen Kommission bei der Bayerischen Akademie der Wissenschaften, Bd. 7 Muenchen 1878, s. 49-50; 
logię na Albertynie. Następnie - tak jak wielu innych niemieckojęzycznych studentów - wyruszył w kilkuletnią podróż edukacyjną na tereny Rzeszy. W 1710 r. w Jenie zdobył tytuł magistra, doktorem teologii został $\mathrm{w}$ tym samym roku na uniwersytecie $\mathrm{w}$ Rostocku. Po powrocie do Królewca w 1711 r. zaczął prowadzić wykłady prywatne. Cztery lata później, w 1715 r. powołano go na stanowisko profesora fizyki ${ }^{22}$. W tym czasie ożenił się z wdową Anną Dorotheą Stürmer, neè Off, której ojciec był mielcarzem i po którym odziedziczyła dobrze prosperujący browar ${ }^{23}$. Kobieta miała dwie córki z pierwszego małżeństwa. Urodziła także jedną z małżeństwa z Fischerem.

Zainteresowany historią naturalną, fizyką, chymiatrią oraz teologią uczony opublikował wiele prac poświęconych tym zagadnieniom, przy czym początkowo zajmowała go przede wszystkim geologia ${ }^{24}$. Założył także i rozwijał prywatną kolekcję instrumentów matematycznych, która w kolejnych latach przewyższyła jego zbiory książko$\mathrm{we}^{25}$. Na Albertynie podczas wykładów z filozofii propagował poglądy Leibniza i Wolffa; angażował się także w próby reformy uniwersytetu. Jednakże jego dążenia reformatorskie, tak jak i jego zaangażowanie w wolffizm, będący dla pruskich pietystów „,solą w oku”, spotkały się $\mathrm{z}$ silnym oporem władz $\mathrm{w}$ Berlinie $^{26}$. W rezultacie 22 listopada

H.F. Klemme, M. Kuehn (red.), The Bloomsbury Dictionary of Eighteenth-Century German Philosophers, London 2006, s. 216-217; oraz innych słowników biograficznych z XIX i XX w.

${ }^{22}$ Zob. jedno z zaporoszeń na jego wykłady: Freundliche Einladung / zu zweyen die Naturlehre betreffenden COLLEGIIS, und einigen dahin gehörigen EXPERIMENTIS. Womit der zu Königsberg in Preußen Studirenden Jugend und andern daselbst befindlichen Liebhabern der Weißheit / instehenden Sommer dieses 1717 Jahres / aufzuwarten gedencket Christianus Gabriel Fischer / PROF. PHYS. EXTRAORD. Dantzig / in Hn. Paul Paters / Mathem. Prof. Publ. Buchdruckerey / und auf dessen Kosten gefertiget, http://cds.library.brown.edu/projects/Gottsched/textDisplay.php?text=fischer.einladung.utf8.caseFixed.unicode.xml [dostęp: 1.02.2020].

${ }^{23}$ I stąd właśnie zainteresowanie Fischera browarnictwem, którą to ciekawość przejawiał raz po raz na kartach dziennika. Zob. np. BPG, sygn. Ms. D.a.85 (vol. II), $\$ 84$.

${ }^{24}$ Zob. m.in. następujące publikacje Fischera: Examen laboris menstrui Theophili Amelii (1712); Erste Grundlegung zu einer ausführlichen Historie des unterirdischen Preußens (1714, wyd. II, 1715); Lapidum in agro Prussico sine praeiudicio contemplandorum explicatio (1715); Muthmaßung von dem aufgehenden Monde, welcher in einem artigen Muschelsteine sich präsentirt (1717); Quaestio philosophica, an spiritus sint in loco (1723).

${ }^{25}$ R. Philippi (red.), G.C. Pisanski's Entwurf einer preußischen Literärgeschichte in vier Büchern, mit einer Notiz ueber den Autor und seine Buch, Königsberg 1886, s. 506.

${ }^{26}$ Urzędnicy Fryderyka Wilhelma I oskarżyli Fischera o krzewienie materializmu, a to ze względu na jego specyficzną, przyjętą za Wolffem interpretację Leibnizjańskiej 
1725 r. Fischer dowiedział się, że w ciągu zaledwie doby musi opuścić Królewiec, a w ciągu 48 godzin musi z kolei wyjechać z kraju. Następnego dnia razem z najbliższymi ruszył w drogę do Prus Królewskich, zatrzymując się na pewien czas w Elblągu. 12 stycznia $1726 \mathrm{r}$. przyjechał do Gdańska, gdzie pod swój dach przyjął go Klein, który tak jak Fischer - urodził się w Królewcu i którego rodzina nadal tam mieszkała. W Gdańsku dzięki protekcji Kleina Fischer rozpoczął wykłady prywatne, podczas których krzewił nauki Wolffa ${ }^{27}$.

Przez kolejne miesiące bliscy Fischera prowadzili wielostronne starania o uzyskanie zgody na jego powrót do ojczyzny. Wszystkie one okazały się jednak daremne. I tak, kiedy w 1727 r. było już pewne, że profesor nie może wrócić do Królewca, przystał on na propozycje Kleina, aby wyruszyć w kilkuletnią podróż edukacyjną z młodym Gerlachem jako jego mentor tudzież

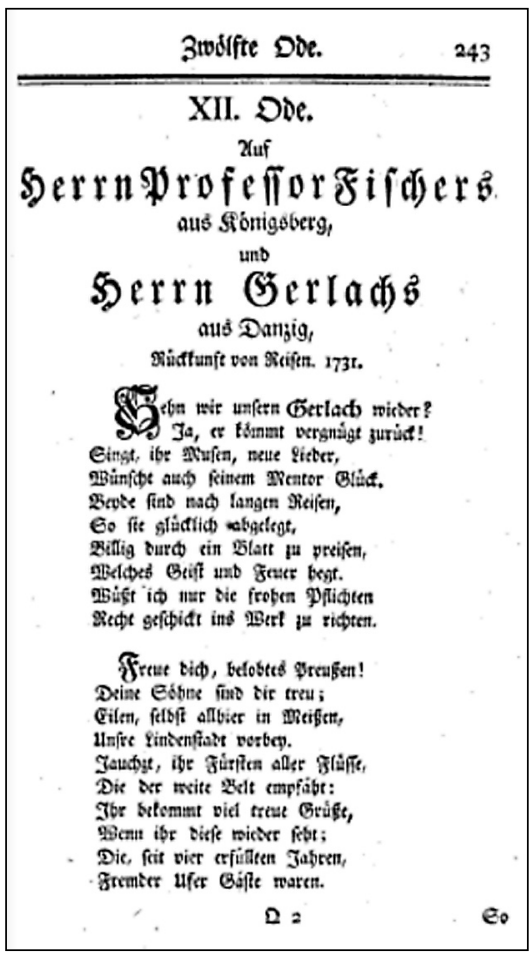

Ilustracja 1. Pierwsze zwrotki ody autorstwa J.Ch. Gottscheda z okazji powrotu Gerlacha i Fischera do Gdańska (1731)

Źródło: zob. przyp. 30. guwerner. Wszystkie koszty podróży miał pokryć Klein, dodatkowo oferując Fischerowi stałą pensję w wysokości 100 talarów na rok ${ }^{28}$.

Fischer i Gerlach wyjechali z Gdańska we wrześniu 1727 r. W kolejnych miesiącach i latach odwiedzili ziemie niemieckojęzyczne, Niderlandy Północne i Południowe, Anglię, Francję oraz Italię (zob. tab. 1). Poznawali największych uczonych tego okresu, m.in. Daniela Gabrie-

harmoniii przedustawnej. Zob. np. R. Pozzo, Kant's Streir der Fakultaeten and Conditions in Koenigsberg, „History of Universities” 2000, vol. XVI, no. 2, s. 112.

${ }_{27}$ S. Salmonowicz, Zwiazki kulturalne Torunia i Gdańska z Królewcem w XVIII wieku, [w:] M. Bogucka, J. Kowecki (red.), Kultura polska a kultura europejska: prace ofiarowane Januszowi Tazbirowi w sześćdziesiata rocznicę urodzin, Warszawa 1987, s. 255.

${ }^{28}$ A. Talle, «Ein Ort zu studieren, der seinen gleichen nicht hat»-Leipzig um 1730 in den Tagebuechern des Koenigsberger Professors Christian Gabriel Fischer, „Stadtgeschichte" 2008, s. 57. 
la Fahranheita, Hermana Boerhaavego i Hansa Sloane'a, oglądali wspaniałe „starożytności”, muzea, biblioteki i ogrody, uczestniczyli w wykładach i demonstracjach - zarówno publicznych, jak i prywatnych, odwiedzali szpitale, manufaktury ${ }^{29}$ i laboratoria, podziwiali fortyfikacje, ludne miasta i skromne miasteczka, krajobrazy itd. Kiedy 12 października 1731 r. powrócili do Gdańska, z okazji ich przyjazdu Johann Christoph Gotsched napisał powitalną odę (il. 1) ${ }^{30}$.

Przy tym Fischer musiał sprawdzić się jako prywatny opiekun studenta, niebawem bowiem został zatrudniony na tym samym stanowisku przez kolejną gdańską rodzinę. I tak, drugą kilkuletnią podróż edukacyjną królewiecczanin odbył z synem kupieckim, Samuelem Huwaertem mł. ${ }^{31}$, odwiedzając z nim kraje niemieckie, Węgry, Niderlandy, Italię, Helwecję i Francję. Pamiątką z tej podróży był kolejny dziennik z peregrinatio academica oraz kilka publikacji przyrodniczych autorstwa Fischera ${ }^{32}$.

W 1736 r. żonie profesora udało się w końcu wyprosić zgodę na jego powrót do Królewca; 5 września Fischer z najbliższymi wrócił do ojczyzny. Dlatego jednak, że nie otrzymał katedry na Albertynie, w kolejnych latach skoncentrował się na badaniach prywatnych. W $1743 \mathrm{r}$. ukazało się jego najgłośniejsze i najszerzej komentowane dzieło, fizykoteologiczna rozprawa Vernünftige Gedanken von der Natur ${ }^{33}$. Uczony zmarł 15 grudnia 1751 r. Rok później na aukcji publicznej zlicytowano jego bibliotekę i kolekcję instrumentów matematycznych ${ }^{34}$.

${ }^{29}$ Zob. np. BPG, sygn. Ms. D.a.85 (vol. II), §. 63. W paragrafie tym opisano wizytę $\mathrm{w}$ lejdejskim warsztacie instrumentariuszowskim Musschenbroeków.

${ }_{30}$ J.Ch. Gottsched, XII. Ode. Auf Herrn Professor Fischers aus Koenigsberg, und Herrn Gerlachs aus Danzig, Rueckkunst von Reisen. 1731, [w:] Gedichte, Bey der itzigen zweyten Auflage übersehen, und mit dem II. Theile vermehret, nebst einer Vorrede ans Licht gestellet von Johann Joachim Schwaben, Leipzig 1751, s. 243-246.

${ }^{31}$ Samuel Huwaert przed wyruszeniem w podróż uczoną z Fischerem jako opiekunem wygłosił w gdańskim gimnazjum akademickim 3 kwietnia 1732 r. dysputę pożegnalną Dissertatio juridica de foemina criminis laesae majestatis rea.

32 PAN BG, sygn. Ms. Uph. $2^{\circ}$, f. 167-170. Z tego okresu pochodzą następujące prace Fischera: Notae et animadversiones ad Plinii Hist. Nat. Lib. IX, Cap. 52: De concharum differentiis („Nova Acta Eruditorum” 1733, s. 487-505) oraz Demonstratio solida de obligatione hominis ad religionem et naturalem et revelatam (1736), a także współopracowana z Johannem Heinrichem Linckiem De stellis marinis tego ostatnigo (1733).

33 J.G. Fischer, Vernünftige Gedanken von der Natur, was sie sey, dass sie ohne Gott und seine allweise Beschränkung unmächtig sey, und wie die einige, untheilbare göttliche Kraft, in und durch die Mittelursachen, nach dem Maaß ihrer verliehenen Würkbarkeit oder Tüchtigkeit, hie in der Welt alles alleine thätig würcke?, b.m.w. 1743.

${ }^{34}$ G. Krause, Gottsched und Flottwell, die begründer der Deutschen gesellschaft in Königsberg: Festschrift zur erinnerung an das 150 jährige bestehen der Königlichen deutschen gesellschaft zu Königsberg in Preussen, Königsberg 1893, s. 159. 
Dzienniki z podróży uczonej Fischera z Gerlachem po jej zakończeniu stały się własnością tego ostatniego, niemniej dostęp do nich miał również opiekun prawny dwudziestokilkulatka, który je zamówił. Klein nanosił w poszczególnych tomach Itinerarium własne notatki oraz wypisy z korespondencji z Fischerem ${ }^{35}$. Od Kleina i siostry Gerlacha - Reginy Concordii pochodziła także część ilustracji, które wzbogacały rękopis. Oryginalny manuskrypt, co warto w tym miejscu zaznaczyć, między 1732 a 1733 r. został przepisany „na czysto” z zeszytów Fischera przez lipskich kopistów - i właśnie w takiej formie trafił do rąk Gerlacha i jego przybranego ojca ${ }^{36}$.

Kiedy Klein w 1743 r. założył Towarzystwo Przyrodnicze w Gdańsku, Gerlach został jednym z jego pierwszych członków ${ }^{37}$. W bliżej nieokreślonym momencie dorosłego życia przekazał do zbiorów Societatis kompletny dziennik swej podróży uczonej, a ten został opisany przez bibliotekarza Towarzystwa jako „Donum Gerlachianum”. Po niemal 150 latach, 1 marca 1923 r. biblioteka Naturforschende Gesellschaft w Gdańsku - w tym Itinerarium Gerlach-Fischerianaum stała się cześcią zbiorów gdańskiej Technische Hochschule. W 1945 r. zbiory biblioteczne - w tym spuścizna Towarzystwa Przyrodniczego - zostały ewakuowane do Turyngii. W 1953 r. dużą część z nich przejęła biblioteka w Bremie. Na progu XXI w., 29 czerwca 2000 r. kolekcja książek i rękopisów dawnej Naturforschende Gesellschaft - w tym osiem tomów Itinerarium Gerlacha i Fischera (tomy I, II, IV, V, VIIIX, XII) - wróciła do Gdańska, do Biblioteki Politechniki Gdańskiej ${ }^{38}$. W 2003 r. brakujący tom VI został zakupiony przez bibliotekę uniwersytecką w Bremie. Tom VII dziennika pojawia się od 2008 r. raz po raz na aukcjach antykwarycznych ${ }^{39}$. Tom III dostępny jest $\mathrm{w}$ bibliotece Technische Universität Berlin ${ }^{40}$. Nie jest natomiast znany los tomu XI, który najprawdopodobniej znajduje się w prywatnych rękach.

O dzienniku podróży Gerlacha i Fischera pisano w literaturze przedmiotu jak dotąd niewiele. W $1778 \mathrm{r}$. informacja o istnieniu dwunastu tomów manuskryptu pojawiła się w „Acta Societatis Physicae Experimentalis” ${ }^{41}$. Wspominali o nich także Georg Christoph

${ }^{35}$ Zob. Aneks [magrinalia].

${ }^{36}$ A. Talle, dz. cyt., s. 59.

${ }^{37}$ O. Schumann, dz. cyt., s. 80.

${ }^{38}$ A. Talle, dz. cyt., s. 59.

39 Zob. np. https://www.antiquariat.de/angebote/GID26759197.html; https://www. auction.fr/_en/lot/frankreich-fischer-christian-gabriel-hrn-nathanael-jacob-gerlach8602297 [dostęp: 5.12.2020].

${ }^{40}$ Zob. tab. 1.

${ }^{41}$ O. Schumann, dz. cyt., s. 80. 
Pisanski w Literargeschichte Preussens ${ }^{42}$ i Friedrich Samuel Bock w Versuch einer wirthschaftlichen Naturgeschichte von dem Königreich Ost- und Westpreussen ${ }^{43}$. Wybrane elementy dziennika stały się inspiracją dla Alberta Predeeka do napisania i wydania w latach 1927-1928 dwóch artykułów, poświęconych życiu naukowemu Lipka oraz różnym bibliotekom ${ }^{44}$. W 2008 r. na częściowo poruszanych już wątkach lipskich Itinerarium skupił się z kolei Andrew Talle ${ }^{45}$. W ostatnich latach nawiązania do wybranych elementów przekazu Fischera pojawiają się w tekstach historyków różnych specjalności, zazwyczaj jednak są to tylko krótkie wzmianki umieszczone w przypisach $^{46}$.

Przedstawiane poniżej w wyborze fragmenty II tomu dziennika podróży Gerlacha i Fischera odnoszą się do ich pobytu w Zjednoczonych Prowincjach oraz tych osób, miejsc i wydarzeń, które wiążą się z nauczaniem medycyny i historii naturalnej. W przytoczonych paragrafach Fischer opisał, jak w Lejdzie w późnych latach 20. XVIII w. wyglądała nauka anatomii, botaniki i chymiatrii; wszakże w tym czasie Academia Lugduno-Batava nadal stanowiła jeden $\mathrm{z}$ najważniejszych ośrodków w zakresie akademickiego kształcenia medycznego ${ }^{47}$. Fischer sporządzał także sprawozdania z wizyt prywatnych u słynnych profesorów lejdejskich (Bernharda Siegfrieda Albinusa i Hermanna Boerhaavego) oraz przygotowywał rozszerzone opisy obron dysput pro gradu na wydziałach prawa i medycyny Academia Lugduno-Batava. Te ostatnie są interesujące $\mathrm{z}$ dzisiejszego punktu widzenia m.in.

${ }^{42}$ G. C. Pisanski's Entwurf einer preußischen Literärgeschichte in vier Büchern, mit einer Notiz über den Autor und seine Buch, hrsg. von R. Philippi, Königsberg 1886, s. 668.

${ }^{43}$ F.S. Bock, Versuch einer wirthschaftlichen Naturgeschichte von dem Königreich Ost- und Westpreussen, Bd. 1, Dessau 1782, s. VII.

${ }^{44}$ A. Preedek, Ein vergessener Freund Gottscheds, w: Festschrift zur Zweihundertjahrfeier der Deutschen Gesellschaft in Leipzig 1727-1927, Leipzig 1927, s. 109-123; tenże, Bibliotheksbesuche eines gelehrten Reisenden im Anfange des 18. Jhs., „Zentralblatt fur Bibliothekswesen” 1928, Jg. 45, s. 221-225.

${ }_{45}$ A. Talle, dz. cyt., s. 55-157. Talle wymienia też wcześniejsze publikacje za wyjątkiem pracy Bocka.

${ }^{46}$ Zob. np. J.E. Gardiner, Music in the Castle of Heaven: A Portrait of Johann Sebastian Bach, London 2013, passim; M. Willes, The curious world of Samuel Pepys and John Evelyn, London 2017, s. 252; U. Stackman, Die Geschichte der chinesischen Bibliothek Tian Yi Ge vom 16. Jahrhundert bis in die Gegenwart, München 1990, s. 13.

${ }^{47} \mathrm{~W}$ rezultacie opuszczono m.in. opisy obserwatorium uniwersyteckiego, licznych drukarni czy rektoratu, a także tych ogrodów prywatnych, w przypadku których nie omawiano roślin lub urządzeń ogrodniczych. O kształceniu medycznym w osiemnastowiecznej Lejdzie zob. np. K. Pękacka-Falkowska, Matthias Ernst Boretius; tam także literatura przedmiotu. 
dlatego, że uzupełniają doniesienia Albrechta von Hallera ${ }^{48}$, dostarczając nowych informacji o przebiegu dysput doktorskich w osiemnastowiecznej Lejdzie. Fischer omawiał również stan zachowania lejdejskich szpitali, m.in. lazaretu ${ }^{49}$, oraz opisywał rozmaite nowinki wprowadzane w prywatnych ogrodach botanicznych i w uniwersyteckim ogrodzie medycznym ${ }^{50}$. Autor dziennika tłumaczył wreszcie, w jaki sposób w Lejdzie wykonywano zabiegi litotomiczne i dlaczego preferowano nowatorskie techniki zabiegowe, jak przechowywano nasiona roślin - lokalnych i obcych, jak klasyfikowano naturalia, ile płacono za udział w kolegiach prywatnych itd.

Oprócz fragmentów dotyczących Lejdy zdecydowano się także przytoczyć w wyborze niektóre z paragrafów dotyczących Haarlemu, Utrechtu, Amsterdamu i Haagi. Między innymi dowiadujemy się $\mathrm{z}$ nich, jak wyglądał teatr anatomiczny w amsterdamskiej Wadze oraz horti medici Harlemu i stolicy Zjednoczonych Prowincji, co znajdowało się w słynnych kolekcjach przyrodniczych Valentina, Ruyscha i innych uczonych, które interesowały Kleina, a także, jak przeprowadzano licytacje spuścizn uznanych zbieraczy. Dodatkowo załączono sprawozdanie z wizyty u pochodzącego z Gdańska wynalazcy termometru rtęciowego Daniela Gabriela Fahrenheita, który cierpiał wskutek zatrucia „merkuriuszem”.

Zaprezentowane $\mathrm{w}$ wyborze źródła mogą stanowić cenny materiał dla historyków medycyny, chemii i botaniki. Z pewnością zainteresują się nim także historycy edukacji i kultury. Wreszcie materiały te mogą być istotne dla gedanistów badających koleje życia dawnych gdańszczan oraz dla ogrodników i architektów krajobrazu, którzy próbują rewitalizować minione sposoby uprawy roślin.

Zasady wydania: Podczas tarnskrypcji wybranych fragmentów rękopisu zachowano jego specyfikę. Nie poprawiano błędów ortograficznych. Nie rozwiązywano skrótów w tekście. Zostawiono oryginalne podkreślenia i skreślenia. Uwspółcześniono zapis wyrazów niemieckich wielką i małą literą, zachowując oryginalną interpunkcję. W nawiasach kwadratowych pogrubioną czcionką [_] wprowadzono nadane

${ }^{48}$ G.A. Lindeboom, Haller in Holland: het dagboek van Albrecht von Haller van zijn verblijf in Holland (1725-1727), Leiden 1979, s. 49-50.

${ }^{49}$ Innym szpitalem był Dom dla Obłąkanych (zob. Ms. D.a.85 (vol. II), §. 37). Ze względu na charakter opisu nie zdecydowano się go przytaczać w Aneksie.

${ }^{50}$ Informacje te musiały być szczególnie interesujące dla Kleina, który zajmował się uprawą roślin egzotycznych oraz opracowywał nowe systemy klasyfikacyjne naturaliów. 
przez autora rękopisu tytuły i/lub śródtytuły w obrębie danego paragrafu. Dokonane przez wydawcę pominięcia w tekście zaznaczono symbolem (...). Rozbudowane marginalia towarzyszące danemu paragrafowi wprowadzono w tekście głównym pod odpowiednim paragrafem, opisując je jako [marginalium]. Do transkrypcji włączono oryginalne ilustracje i szkice $\mathrm{z}$ rękopisu.

Fragmenty II tomu Itinerarium Gerlach-Fischerianum, odnoszące się do dziejów medycyny, historii naturalnej (w tym kolekcjonerstwa przyrodniczego) i filozofii natury w Niderlandach Pólnocnych późnych lat 20. XVIII w. - część I (Lejda)

Haga

§. 4 .

[Valentinische Muschel-Auction im Haag.] Novembr. d. 27. ${ }^{51}$ diesen Tag war die Auction der Valentinischen Raritäten, im Haag. Der vormahliger Besitzer, Franciscus Valentyn ${ }^{52}$, war Prediger in OstIndien, aus Amboina und Banda gewesen, und hatte eine schöne Collection von Schnecken und Muscheln, und einigen Corallen Gewächßen, item, von einigen Thierchen in Spiritu Vini, gesamlet. Die ganze Collection befand sich in 2. Nußbaumen Schräncken, worauf die Corallen-Gewächse und die Thieryen zu sehen. /: vid. Catalogus, van een uit muntend Heerlyk, Cabinet etc. in $8 .{ }^{\mathrm{vo}} \mathrm{Nr}$. $1 .: /$ Weil ich in Commissis hatte, in diese Auction mit einzusehen, und einige Defecten zu acqviriren, war zwar Willens, Tages vorher, nach dem Haag zu reisen; Aber es befand sich Hr. Gerlach nicht recht wohl, und schiene fast eine Disposition zum Fieber zu haben: Weßwegen Er, und Ich, ihm zur Compagnie, den 26. zu einem vomitiv resolvirte. Ob wir nun wohl unß Tages darauf mercklich beßern befanden, blieb Hr. Gerlach doch, zum Theil auch wegen des schtechten Wetters zurück: Ich aber, und Hr. Öhmchen, fuhren Morgens frühe, mit der Schüte nach dem Haag, da wir denn bey unserer Ankunfft, umb 10. Uhr, Morgens, ingesamt nach dem Princen-Hoff uns begeben, allwo in einem Buchladen die Sachen ausgeruffen wurden. Man hatte eben die Conchilia vor, welche Paar weise an den meistbietenden verkaufft wurden. Es fanden sich dabey 5. biß 6. Mäckler, welche die Schnecken nach dem

$511727 \mathrm{r}$.

${ }^{52}$ François Valentijn (1666-1727) - naturalista i misjonarz, w latach 1724-1726 wydał Oud en Nieuw Oost-Indiën. Więcej o nim zob. J. Fisch, Hollands Ruhm in Asien. François Valentijn Vision des niederländischen ImperiuMs. im 18. Jahrhundert, Wiesbaden 1986. 
Catalogo, ob sie gleich nicht numeriret waren, erkandten, und, nach der Größe, Farbe, und andern Zufälligkeiten aestimirten. Darunter waren auch Frauen Zimmer, welche nicht wenige Käntniß und Lust zu dergleichen Kraam bezeugeten. Die Specimina an sich waren schön, aber alles bekandte Species, die wenige unbekante Kleinigkeiten, und Species Specialissimae waren zu theuer, alß daß man sie einzeln bezahlen konte. Unter den Thieren in Spiritu vini sahe nichts unbekantes, auch nichts dergleichen unter den Corallen Gewächßen; die Species ramosae, und die Panaches, waren auf Pedamenta von Wallfisch Knochen, oder, auf poros Corallinos geküttet. Umb 1. Uhr hörete man Vormittag auf zu auctioniren. Weil wir im Parlament von Groß-Britannien uns zur gewöhn. Mahlzeit nach 2. Uhr melden laßen, hatten wir noch Zeit etwas in den Straßen uns umbzusehen. Hie war es nun viel lebhaffter, alß zu Leiden, man merckte auch nicht Febricitanten; wegen des trüben neblichten Wetters aber, war nichts außerordentliches in den Straßen zu sehen. In dem vortrefflichen Gasthoff fanden wir eine starcke vornehme Compagnie von Teutschen, und Holländern. Nach der Mahlzeit, giengen wir wieder umb 3. Uhr, nach der Auction, welche umb 5. Uhr vor heute geschloßen ward. Weil nun bey der Auction kein Profit abzusehen, resolvirte mit der AbendSchüte wieder nach Leiden zurück zu kehren. Mitterweile bezahlten wir unsere Mahlzeit und Ausgaben im Qvartier, zusammen 6 F. ${ }^{53}$ Holl. und traten, biß zur Abreise, in ein Caffè Hauß, wo wir Zeit mit Avisen lesen passireten. Auf dieser Spazierfahrt habe gelernet: 1.) daß im Haag, aus Auctionibus, ohne Mäckler und Commisionaires etwas zu kauffen, vor Fremde zu pretieux sey. 2.) daß die Mäckler, so dergleichen Einkauff besorgen, nicht eben zu viel Provision anrechnen. 3.) daß im Haag mehr Liebhaber auf Curiosa alß anderwerts lauren, maßen die Gesandte, und derselben Bediente, so wohl vor sich, alß vor andere auswertige Liebhaber dergleichen Sachen einkauffen. 4.) daß, dagegen, aus Bücher Auction, wegen ihrer Freqvence, mehr Profit zu machen, und dazu der Büchführer Wischoff ${ }^{54}$, zu Leiden, gar wohl zu employren. 5.) daß, wer von Etats-Sachen in der Welt lernen will, im Haag sich umbsehen, aber auch dabey auf eine kluge Menage bedacht seyn müße.

${ }^{53}$ F. (Fl.) - floren.

${ }^{54}$ Conrad Wischoff - księgarz i wydawca lejdejski. 


\section{Lejda}

§. 5.

[Hortus Medicus generaliter beschrieben.] Novembr. d. 29. Gieng Hr. Gerlach nach der Mahlzeit, in den Hortum Medicum: daran das Kupffer, nebst der Beschreibung, in den Delices de Leide, p. 75. ${ }^{55}$ und ein größeres Kupfer im Volumine Iconum Leidensium ${ }^{56}$, zu finden. Mein Absehen war bey dieser späten Jahres Zeit zu sehen, wie man die Gewächße gegen den Winter versorget. Die Gewächße, so die Kälte nicht wohl vertragen, waren alle unter Dach gebracht; Im Garten Feld, welches in lange Rabatten vertheilet, und, mit hölzernen Rähmen eingefaßet ist, stunden die Kräuter noch bloß in Reihen, noch ihren Speciebus, mit beygesteckten hölzernen Numeris, laut dem Indice des Hr. D. Boerhawens, rangiret. Von jederer Sorte befinden sich wenige Pflanzen, und diese wachsen so dicht an einander, daß ich mich wundere, wie man ein Gewächß vor dem andern conserviren könne. Die Gänge zwischen denen Rabatten sind schmal, weil der Garten um sich, nicht viel über 200. Schuh ins Gevierte hält. Durchgehends siehet man hier nichts von Gärtner-Architectur-Sachen, vielweniger von Bilder Werck. Unter den Kübels, Töpffen, und HülffStüben ist keine Symmetrie, noch einiger Zierath. Es pranget allhier, welches nach Academischer Absicht, zu loben, der bloße Reichthum der Natur. Weil der ganze Garten mit einer Mauer umbgeben, und an dreyen, Morgen- Mittags- und Abend-Seite, mit Galerien bebauet, so sind diese zwar massiv, aber nicht hoch, noch sehr geraum, vielweniger kunstlich angeleget. Umb, den Begriff davon etwas deutlicher zu machen, will das Kupfer dans les Delices de Leide allhie, mit angesezten Buchstaben erklären.

A. Der Academische Thurm.

B. Das Observatorium.

C. Eingang auf den Vorhoff der Academie.

D. Der vortreffliche Buchladen des von der $\mathrm{Aa}^{57}$, und deßen kostbaren Druckerey.

E.

F. Entrèe in den Garten vom Acadamischen Platz.

G. Schöne Wohnung des Professoris Botanicae.

${ }^{55}$ Les Délices de Leide: une des célébres villes de l'Europe: le tout enrichi de tailles douces, A Leide: chez Pierre Vander Aa, 1712.

${ }^{56}$ Więcej nt. tego zbioru portretów: R. Ekkart, Icones Leidenses. De portretten verzameling van de Rijksuniversiteit te Leiden, Leiden 1973.

${ }^{57}$ Pieter van der Aa (1659-1733) - księgarz lejdejski specjalizujący się w wydawaniu map i atlasów. 
H. Galerie / , zu den Naturae curiosis. vid. les Delices de Leide. pag. 77. I.K. Mauer zu Ende des Gartens am Graben.

K.L. Galerie, zu Gewächßen.

M.G. Eisernes Gegitter vor dem Garten.

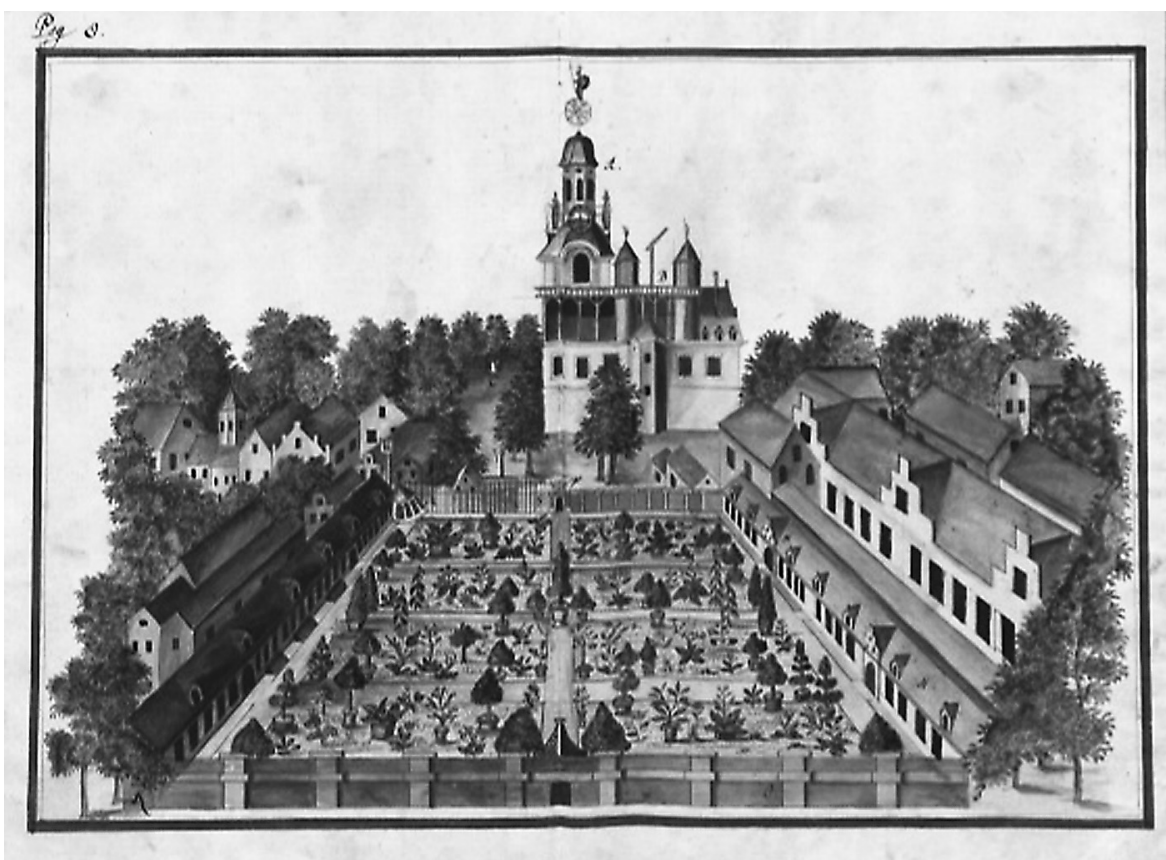

In angewisener Galerie, K.L. finde die Gewächß sehr dicht zusammen stehen, und, mit wenig Wärme, vielweniger Sonnen-Hize versehen. Es stehet hin und wieder ein kleiner eiserner Ofen, aber jetzt waren noch Thüren, und einige Fenster offen. Die Gewächße sind mehrentheils kleinstümmig. Ich werde in folgenden von ihnen insbesondern melden. In einem Departament dieser Galerie ist ein großer Schranck mit Schaubladen, in lauter kleine Fächlein getheilet, darinn allerhand Saamen liegen. An der Mauer K.I. stehen allerhand frembde, hochstümmige Bäume, item, allerhand hochlauffende Ramken. Solche Gewächsen sind auch die Pfeiler der Galerien, zwischen den Fenstern, und die Dächer gewiedmet; In der Ecke bey I. sind einige Behaltniße vor ausländische Thiere, abgeschlagen. Jetzt ist nichts mehr, alß ein Indianisches graues Schwein darinn zu sehen [Indianisches Schwein.]; Selbiges ist so groß, alß ein jährig gemeines Schwein, straub von Haar, etwas kurzer von Kopff, und hat auf der linken Seite, unter der Spina dorsi, noch hinten, gleichsam eine 
Wunde, eines Dutzen groß, woraus ein gelbishter Mucus grillet. Ich erinnere mich, dergleichen Schwein in Valentini Museo Museorum ${ }^{58}$, aber nicht ohne Fehler /: die Wunde ist conisch gemahlet :/ abgebildet gesehen zu haben: davon die Specification in den Delices de Leide zu finden. Đie Sachen sind mehrentheils alt, und übel conserviret. In einem Schranck mit Glaß-Fenstern, sind allerhand Collectanea, zur materia medica gehörig, ex Regno minerali, in Gläßern, aber mehren theils, voraus qvvad Salia, verdorben. In einem andern Schaff sind Marina, alß: Corallia, Fuci, und Spongiae, welche Hr. Boerhawen in Indicis alterius P. 1. recensiret. So viel alß ich durch die Glaß-Fenster erkennen kann, sind viel Species schon bekandt, und, das meiste, zu Dresden, in ansehnlichern Stücken zu sehen. Mit der Zeit behalte mir vor, diese Sachen genauser zu examiniren.

\section{§. 6.}

[Rare Blumen und Vogel Gemählde, bey Hr. Boerhawen] Decembr. d. 4. besuchte mit Hr. Gerlachen, Hr. D. Boerhawen. /: siehe deßen Portrait, in Iconibus Leidensibus :/ was von deßen Person und conversation rühmliches allhie melden könte, habe in einem Brief an Tit. $\mathrm{Hr}^{\mathrm{n}}$ Secret. Klein, nach Danzig, unter dem 14. hujus, einfließen laßen; Weil ich nun hoffe, daß dieser Brieff nebst gegewertigen Journal wird ausgehoben werden, erachte vor unnöthig, die Momenta daraus auszuführen. Was ich im Briefe übergangen, ist, die wohlgefällige Arth, seltsame Blumen aus dem Horto Medico, mit lebhaffen Oelfarben, auf ansehnlichen Schildereyen vorzustellen, dergleichen im Salon des Hr. Dr. Boerhawen, der in den Hortum Medicum die Aussicht hat, in ansehnlicher Reihe zu sehen. Weil es zu weitläuffig fallen sollte, ganze Pflanzen auf besondern Bildern, in Lebensgröße zu praesentiren. Sind die raresten Blumen und Fruchte in allerhand Rangements, mit etwa einem und dem andern Blat, nach Arth der Brabandischen BlumenStücke, geschiltert, alß lägen sie in Schlußel-Körben, oder Bloß auf Tischen, etc. Jede Blume, oder Frucht, ist in LebensGröße natürlich gemahlet, und, mit allen Theilen, auch nach allen Veränderungen $\mathrm{zu}$ sehen. Welches eine große Curiositè ist, so recht zum Horto Botanico gehöret. In einem andern Cabinet, da Hr. Boerhawen studiret, sind, an der Wand, 15. biß 18. Stück schöne Schildereyen von Vögeln,

${ }_{58}$ M.B. Valentini, Museum museorum, oder Vollständige Schaubühne aller Materialien und Specereyen, nebst deren natürlichen Beschreibung, Election, Nutzen und Gebrauch ... aus andern Material-, Kunst- und Naturalien-Kammern, Oost- und WestIndischen Reise-Beschreibungen ... also verfasset und mit ... Kupfferstücken unter Augen gelegt, Frankfurt am Mayn: In Verlegung Johann David Zunners, 1704. 
nur mit Wasßer =Farb, auf Papier, unter Glaß rangiret. Die Kunst ist davon recht ungemein, und wäre zu wünschen, daß dergleichen Collection in Kupfer gestochen undalso illuminiret werden könte.

[marginalium] Extract: vom 14 Dec: Den 4. h. haben von 4. bis halb 6. Mittags bey Hr. D. Boerhaven audienz gehabt; beym Eintrit in sein Staat-Zimmer machte groß Augen, wegen der schöne, und Professorib. ungewöhnlichen Meubles. Die Wänden sind rund umb gantz mit Schildereyen der schönsten Bluhmen des Horti Medici in allerhand Rangements behangen: von dannen wurde mit M. Gerlach in die Studier Stube genöhtiget, woselbst Hr. B: mit bloßen Kopf am Fenster, hinter einem kleinen Tisch saß, vor welchen Er uns weit von dem angefeürten Camin zu sitzen nöthigte. Hinter ihm an der Wand war eine kleine Samlung vor gemahlter Vögel. Nach geendigten Complimenten discurirten wir occasione Horti Medici de Cultura Plantarum etc. Ich erwarte auch von ihm 2. Exemplaria von Vaillant ${ }^{59}$, eines von Eh. das andern vor Hr. M. Hellwing ${ }^{60}$. Der Graff Marsilli hat einige Monaht alhie mit Hr. Boerhaven conversiret, und ist noch bey ihm wohl angeschrieben. Aus einem Brief, den Michelli ${ }^{61}$ aus Italien zwar unter, aber nicht gantz geschrieben wollte Hr. B. mir [wyraz nieczytelny], daß Michelli nur bey einer gelehrten Societè unter dem Praesidio des Abt Totzi $^{62}$, der de fungis schreibet, Handlange und so pauvre als fleißig bey $\mathrm{Hr}$. Scherard ${ }^{63}$ soll ihm, da Er in Italia gewesen, Handreichung gethan, haben, davon Er einen E. zu seinen Excursionibus Botanicis hat halten mögen. Seine Alcyonia und Spongies welche Er aus Licht bringet, machen in der Botanique eine neue [wyraz nieczytelny], welche Marsilli gleichfals laut meiner eigenen Erfahrung praetendiret. Was bisher de Alyconiis geshrieben, will Hr. Boerhaven nicht gefallen. Die genera Corallorum will er auch nicht ohne angescheinliche Experience zu bestimmen ihm getrauen; jedoch hält er die Difference inter ceratophyta et tetanoceratophyta vor essentiel. Jenes sind glatte harte MeerGewächste die in Chymischer Untersuchung den Geruch und die principia der Hörner von Thieren halten; dieses aber sind harte Meergewächse, die mit einer irdenen Kinde umbgeben sind,

${ }^{59}$ Sebastien Vaillant (1669-1722) - botanik francuski. W 1723 r. ukazał się jego Prodromus, w 1727 - Botanicum Parisiense.

${ }^{60}$ Georg Andres Helwing (1666-1748) - pastor i botanik z Angerburga (dziś Węgorzewo) w Prusach.

${ }^{61}$ Pier Antonio Micheli (1679-1737) - botanik włoski, profesor na uniwersytecie w Pizie.

${ }^{62}$ Don Bruno Tozzi (1656 - 1743) - botanik włoski, wallombrozjanin.

${ }^{63}$ William Sherard (1659-1728) - angielski naturalista i botanik. Członek Royal Society. 
aus derer unsehichen poris, so man auf ihrer Superfice siehet, lauter neue plantae anwachsen etc etc Es soll Hr. Boerhaven ein MSCt: vom Swammerdam ${ }^{64}$, zu Händen kommen seyn, welches lang in Engeland gestecket; aus selbigem vermuhte die arcana anatomica, welcher der author in seiner historia insectorum ${ }^{65}$ hie und wieder allegiret. Man hat Hofnung, daß es heraus kommen werde. Nun arbeitet Hr. B an der Chymie welche er sehr verlanget wird.

[marginalium] Extract vom 1. Nov: die 1sten lectiones des Hr. Boerh: nach der Kranckheit habe mit plaisir angehöret. Est vir vere

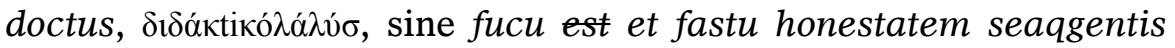
simplicitaetem habitu et gestu exprimens, hir in Leyden ist Er Doctor Senator, Consul, oia tresq. Ihm fließt Geld und Ehre von allen Ecken $\mathrm{zu}$; mich wundert seiner modestie!

\section{\$. $7 \mathrm{~b}$.}

[Personalia von Hr. D. Albino] Decembr. d. 10. gieng mit Hr. Schreibern zu Hr. D. Albino ${ }^{66}$, /: deßen Portrait in Iconibus Leidensibus zu sehen :/ hiesigem Profess. Anatomiae, et Chirurgiae, umb, deßen Bekannt- und Freundschafft zu suchen. Wie mir deßen Person und Conduit gefallen, habe in vorgedachtem Brief an Tit. Hr. Secr. Kleinem, gemeldet: Sein Vater ist, von Franckfurt an der Oder, zum Prof. Medicinae hieher vociret worden. Selbiger ist ein liberaler und conversabler Mann gewesen, der die seinigen zwar honett erzogen, aber nicht mit zulänglichen Reichthumb so glückl. machen können, daß die wohlgestellten Tochter verheyrathet werden mögen. Die beyden annoch unverehelichten Söhne sind Medici, und beyde Profess. Anatomiae: Einer allhie zu Leiden, der andere zu Utrecht. Der zu Leiden, ist ein junger, schöner Mann, wenig über 30. Jahr, etwas steif auf der rechten Hüffe, nach seines Vaters Exempel gebohren, hat in Engelland die Antomie, und, in Franckreich die Botaniqve studiret: Hr. Boerhawen hat Ihn, da man D. Heistern ${ }^{67}$ von Altdorff zur vacanten Prof. Anatomiae hieher ruffen wollen, umb die Familie zu conserviren,

${ }^{64}$ Jan Swammerdam (1637-1680) - niderlanndzki przyrodnik i medyk. Więcej o nim zob. L. Kooijmans Niebezpieczna wiedza. Wizje i lęki w czasach Jana Swammerdama, Warszawa 2010.

${ }^{65} \mathrm{~J}$. Swammerdam, Historia insectorum generalis, t'Utrecht 1669.

${ }^{66}$ Bernhard Siegfried Albinus (1697-1770) - niemiecko-niderlandzki anatom, profesor wydziału medycznego na uniwersytecie w Lejdzie, twórca tamtejszej kolekcji preparatów anatomicznych.

${ }^{67}$ Lorenz Heister (1683-1758) - niemiecki chirurg, botanik i anatom. 
aufs beste recommendiret, und zur Profession, die Er jetzt mit großen Ruhm bekleidet, gefordert. Nun ist er seiner Kunst völlig gewachßen, und, da es Ihm weder an Gelehrsamkeit, noch an Erfahrung, weder am Geschicklichkeit noch Conduit fehlet, dabey das alten Ruyschen Kunst-Griffe, im injiciren ${ }^{68}$ vollkommen verstehet, so hat man von Ihm die Hoffnung, daß Er alle bißherige Holländische Anatomicos mit den Jahren übersteigen werde; Zur Praxi trägt er kein belieben: dagegen adspiriret er mehr zur Botanic, bißher hatte Er die Osteologie erkläret, und ins besondere de generatione ossium in infantibus, curiosas observationes und collectanea vorgebracht. Vor wenig Tagen war mit in seinen Lectionibus, und sahe in seinen Händen ein cylindrisches Glaß, mit sehr hellem Spiritu Vini, darinnen die Cartilagines Laringis von einem Embrione von 3. Monathen sehr fein und sauber excarnirt, an einem Pferde-Haar hiengen. Von einem etwas ältern foetu, hat Er das os yoides trocken, und, in einem subtilen flachen Schaub-Kästlein die ossa cranii von vorgedachten Foetu trimestri, so zart und fein auf blau Papier aus einander gefliehen, und zum Theil angeleimet, damit die nicht der Wind, oder Athem wegblasen möchte. Nun folget in seinem Cursu Medico, oder Anatomico-Pysiologico-Chirurgico, die Myologie, wozu er bereits diesen Tag ein Subjectum zur Hand bekommen, und, welches er Morgen zu demonstriren anfangen wolte: Nehmlich, daß ich hievon bey dieser Gelegenheit Erwehnung thue: So hält Hr. Albinus in seinen Lectionibus diese Ordnung; gegen den Winter lieset er die Anatomie [Seine methode in Anatomicis, et Physiologicis.], ins besondere, die Osteologie, biß gegen Weynachten. Umb diese Zeit, seciret Er privatim ein Subjectum zur Myologie, welches Er aus den Hospitälern acqviriret, und zu seinem Vortheil praepariret. Wer das seciren zusehen will, muß 5. Rthtlr. ${ }^{69}$ und, wer mit Hand anlegen will, 15. Rthtlr. zuzahlen. Nach dem Fest, mit dem Neuen Jahr, wird ein justificirter Deliqvent, aus der Province, zur öffenlichen Anatomie geliefert: daran wird die Spalnchnologie, und ein Theil ins besondere, ex professo tractiret. Nachmahls stellet Er noch eine privat-Section zur Angiologie und Nervologie an: wozu er ein frisches Subjectum anschafft. Umb das andere Jahr, werden zwey Subjecta publice anatomiret, an deren einem, die Chirurgischen operationes gewiesen werden. Wer bey Hr. ${ }^{\mathrm{n}}$ Albino die Osteologie, Myologie, und übrige Sectiones

${ }^{68}$ Frederik Ruysch (1638-1731) - niderlandzki anatom i medyk, jeden z popularyzatorów metody wstrzyknięć z wosku w trakcie wykonywania preparatów anatomicznych. Więcej o nim zob. L. Koojmans, Death Defied: The Anatomy Lessons of Frederik Ruysch, Leiden 2011.

${ }^{69}$ Rthtlr (Reichsthaler) - talar, moneta srebrna. 
freqventirt, zahlet 15. Rthtlr. Gegen das Vorjahr, lieset Hr. Albinus die Physiologie, über seine Praeparata, welches ein sehr schönes und nuzbares Collegium seyn soll; Davor werden Ihm wiederumb 15. Rthtlr. gezahlet: und, vor die darauf folgende Chirurgie, 5, Rthtlr. Die Cadavera, so publice anatomiret werden, geben Sceleta, und Praeparata zum Theatro Anatomico; Was aber von privat-Sectionibus sich asserviren läßet, bleibt Hr. D. Albino eigen.

[marginalium] Extract d. 4 Dec. D. 10 habe Hr. D. Albinum besucht, und viele Vergnügen in seiner Bekandschafft gefunden. Er ist ein feiner junger und annoch unverehligter Mann, von ungemeinen Fertigkeit und Kunst in Anatomicis. In realitè und gründlicher Wißenschafft wird Er bereits dem alten Ruysche vorgezogen, und im Praepariren giebt Er ihn nichts nach. Ich habe in seiner Osteologie die er vor wenig Tagen absolviret, Sceleta Embryonum von ungemeiner Subtilite wahrgenommen, und nun da ich ihn in der Myologie anatomiren sehe, gefält Er mir über aus woll. Er hat auch mit Marsilli conversiret, und judiciret nach des Graefen flüchtigem und soldatischem humeur, daß der Danubius Pannonicus die vermeinte accuratesse kaum haben könne. Nach dem die Osteologie das Hr. Albini allgemeinen applausum gefunden, wird numehro seine Myologie folgen. $\mathrm{Er}$ bemühet sich nicht so wohl umb neue Decouvertes, als umb Gewisheit des, was bereits in anatomicis, aber offt Iconifelhafft entdrucket ist. Weil Er selbst keine Schemata stechen läßet, sonderlich stets auf Vesalium $^{70}$ und Eustachium ${ }^{71}$ beziehet, muß man beyde, ihn zu verstehen, zur hand haben. Vesalium zwar, umb Gesicht, Eustachium aber umb dem Verstanden zu helffen. Von dies. hat die Holland: Edition ${ }^{72}$ in Kupfern einige fehlet, weswegen man die Römische ${ }^{73}$ höher aestimiret. Hr. Albinus ist umb eine beßere Erklahrung der Tabellen angesprochen worden, er will aber dem Morgagni ${ }^{74}$, der damit zu Werck ist, nicht fort thun etc.

${ }^{70}$ Andreas Vesalius (1514-1564) - flamandzki anatom, uważany za ojca nowożytnej anatomii opisowej.

${ }^{71}$ Bartolomeo Eustachi (ok. 1500/1510-1574) - włoski anatom.

72 Autor nawiązuje do wydania amsterdamskiego z 1722 r. z oficyny Gerarda Wetsteina (Tabulae anatomicae... Bartholomaei Eustachii, quas e tenebris... vindicatas... praefatione, notisque illustravit... Jo. Maria Lancisius...).

${ }^{73}$ Autor odnosi się do rzymskiego wydania Tabulae anatomicae clarissimi viri Bartholomaei Eustachii..., które wyszło spod ręki Giovanniego Marii Lancisiego w 1714 r.

${ }^{74}$ Giambattista Morgagni (1682-1771) - włoski anatom i patolog związany z uniwersytetem w Padwie. 
§. 8.

[Beschreibung der privat-Anatomie.] D. 17. Decembr. heute fieng Hr. D. Albinus an, in Myologicis, von 10-11. Morgens, und 5-6. Abends zu demonstriren. Weil ich selbst ein Liebhaber von der Anatomie bin, und darinn gern bey Gelegenheit mich beßern mag, versäumete nicht, diesen Demonstrationibus beyzuwohnen; der Orth, wo pivatum seciret wird, ist das Consistorium gegen über der Englischen Kirchen, wo die Kirchen-Väter dieser Gemeine Unterredung halten. In selbigen wird auch von einem Lectore Matheseos, die Architectura militaris gelesen. In der obern Etage ist die große Bibliothec; das Gemach ist hoch, etwa 50. Fuß ins Qvadrat, hat an der einen Seite 2. hohe Fenster, mit Vorhängen. Gegen über den Fenstern, ist ein Catheder, mit einer großen schwarzen Tafel, an dem übrigen Wänden hangen Modelle von allerhand Manieren, zu fortificiren. An der Linken Wand, vom Catheder zu rechnen, ist ein großer Camin. Mitten im Zimmer ist ein runder Schausplaz mit Bäncken erbauet: dergleichen in den Delices de Leide, p. 83. abgemahlet, und von mir anderwerts accurat beschrieben ist. Der Numerus Auditorum, bey dieser Anatomie, belieff sich auf etliche 70. Studiosos Medicinae und Chirurgiae, von allerhand Nationibus, besonders Engelländern, Holländern, Teutschen, Schweden, Dähnen, Rußen, und Schweizern, worunter viel alte und auch promovirte waren. Zum Anfang muste ein jeder seinen Nahmen anzeihnen, und einen Holl. Schilling, oder 6. Stüver, an den Diener des Hrn. Albini zahlen. Bey der Demonstration wurden die Vorhänge vor die Fenster gezogen, und ein Licht zu Füßen der Leiche gestellet; Neben dem praeparirten Theil aber, wovon der D. redet, durch einem Studiosum ein doppeltes Wax-Licht gehalten. Wie die Leiche bedeckt, tractiret, und alles in gehöriger Ordnung demonstriret worden, habe umbständlich in meinem Latinischen Notis, ad Heisteri compendium anatomicum $^{75}$, aufgezeichnet. Gegenwärtiges Subjectum war ein alter ganz vertrockneter Kerl, an welchem nichts außerordentliches, alß, and den Vasis emulgentibus, bey den Nieren, vorkahm, maßen 1.) die Vena emulgens sinistra, unter der Aorta nach der lincken Nieren sich hinstreckte: welches Eustachius nicht observiret. 2) Eine doppelte $A r$ teria emulgens nach der Licken Niere zuliess: wovon Eustachius schon Erfahrung gehabt. Diese Anatomie dauerte biß aus den dritten Feyertag, bloß die Sontage, und den ersten Christ-Freytag ausgenommen.

${ }^{75}$ Compendium Anatomicum totam rem anatomicam brevissime complectens zostało wydane w 1719 r. w Altdorfie-Norymberdze przez oficynę Kohles-Adolph. Praca ta doczekała się licznych edycji i przekładów na języki wernakularne. 


\section{S. 16.}

[Pesthauß beschrieben.] Decembr. d. 21. Gieng mit Hr. Gerlach in das hiesige PestHauß, umb, die schüne Anstalt darinne zu sehen, welche in den Delices de Leide, p. 200 gerühmet wird. Selbiges ist, Anno 1653. von allerhand Legatis, und Collecten erbauet, biß dato von denen dazu gesamleten Interessen, da es, seit 1663. nicht hat dörffen gebraucht werden, trefflich gebeßert, und bereichert worden. Das Gebäude liegt, wie im gedachten Buch gemeldet, am einen plaisanten Orth: [Fig. 1.] ist ein viereckigter Plaz, etwa von 200. Schuh, ins Gevierte, von lauter Ziegeln bebauet, etwa 24 . Fuß hoch, biß unter das Holländische Dach, und, mit einem breiten Graben rund umb, umbgeben. Wenn man durch die Alleè vor das eiserne Thor-Gegitter (A.) komt, wird mit einer Glocke dem Pest-Vater ein Zeichen gegeben, welcher alßdenn, bey Thor öfnen einen Stüver in die Büchße fordert. Auf dem schönen Plaz, (.A.B.C.D.) vor dem Pesthause, wohnet zur Lincken bey (B.) der vorgedachten Pest-Vater, ins besondere. Zur Rechten Hand gehet man über eine Brücke, (C.) [Fig. 2. Fig. 1.] in das rechte Gebäude, allwo man in der Entreè (a.) nichts, alß einige Thüren, eine lange schwarze Tafel, eine Treppe zur lincken Hand, und an der Thüre einen Pfost mit einer zierlichen GeldBüchse wahrnimt. Die Treppe zur lincken Hand hinauf, gehet man in den Vorsteher-Saal, (b.) allwo eben gegen den morgenden Neujahres-Tag, eine große Tafel gedecket, und gezieret war, vor die Herren Vorsteher, und Frauen Vorsteherinnen, die alßdenn zusammen kommen. An den Wänden dieses Saals, waren, außer dem Grund-Riß, dieses Gebäudes, verschiedene Tafeln, auf welchen die Nahmen und Wapen der Vorsteher, und der Vorsteherinnen, wie sie auf einander gefolget, zu lesen. Oben an im Saal, sind die Register der Frauen Vorsteherinnen, welches nicht jedern Zeit der Vorsteher Ehefrauen, sondern auch andere honette Dames sind, die zu dergleichen Ämtern gezogen werden. Über dem Camin (C.) sind auch an den Leisten allerhand Vorsteher Wapen ausgeschnizt, und gemahlet. Im mittlern Felde aber ist das schöne Bild einer verpesteten Frauen, mit ihren zarten Kindern, welches man von einer Capitain Frau, so im Pesthauß damahls gestorben, expliciret. Unter dem Saal muß vermuthlich ein Keller, oder eine Speise-Kammer seyn, die nicht gewiesen wird. An eben der lincken Seite, unter der Treppe, geher man aus der Entreè (a.) durch (d.) in die 8. egale Salons, wo die Krancken gebettet werden. Selbige sind auf 50. Fuß lang, 30. breit, und über 20. Schuh hoch; die Brüstung der Fenster ist fast 12. Schuh. Die Lichter von 4 . Fenstern, derer 2. 
unterste hölzerne Laden von draußen haben, sind 10. Schuh hoch, und 5. Schuh breit; zu Ende eines jeden Saals ist ein großer Camin, (i) der zugleich die Küche vor dem Saal abgiebet. An den Wänden stehen die eichene Bett-Stätte, auf 2. Personen (e.e.e.) recht zierlich, wie PferdtStände abgetheilet, und unter an Seiten-Felde numeriret; darinnen ist nichts alß ein Unterbett, und das zwar nur in dreyen Stuben zu sehen; gegen über dem Camin, an der andern Wand, sind verschloßene Bett-Schaffe (f.) vor rasende und verrückte Krancken. Item, ein Spind (g.) mit Schaubladen, zu allerhand Medicamentis. In den Frauen-Stuben sind über den Bett-Stätten an der Wand, Regale, Röcke und allerhand Sachen zur Hand zu legen; der FußBoden ist durchgehends mit steinernen Fließen ausgeleget, und unter den Betten mit Ziegeln ausgemauret. Zur Pest-Zeiten, da großes Feuer beständig im Camin brenneet, soll alle 2. Stunden Waßer mit vollem Eimern auf die Bodens gegoßen werden, sonder zweifel die inficirte Lufft zu praecipitiren, und den Krancken ungefährte Respiration zu schaffen. In jedes Saals lincken Seite ist ein beqvemes Secret, (K.K.) und, rechter Seite sind zwey doppelte Thüren (h.h.) [vid. Fig. 1.] auf den innern Plaz zu gehen. Dieser hat 4. Großen, mit Mauer eingefaßte Blümen-Felder, 2. rund umb, mit hochstämmigen Bäumen besezt. Mitten durch gehet ein Graben (F.) zum Kleider waschen, und anderer Beqvemlichkeit; die Gänge, umb, und zwischen den Blümen-Feldern, sind mit Holländischen Mopchen ${ }^{76}$ ausgemauert; Am Gebäude gehet rund umb, unter einem breiten, [Fig. 2] mit Bley gedeckten, und, auf Säulen ruhenden Altan (G.) ein schöner Spazier-Gang, gleichfalls mit Klinckers gepflastert, zur grosten Commoditè der gewesenden, welche hierunter frische Lufft schöpfen können. Über den Salons sind die großen verschloßenen Söller, und Korn-Boden. Von Hauß-gerähte siehet man im Gebäude nichts, alß einige wenige Keßel, Schleiffe, hölzerne und beschlagene Kannen, Nachtkannen, Bettwäemer, etc. Wenn man aus diesem großen Gebäude komt, stehet zur Lincken, an der Mauer über dem Graben, Ein, aus Bley gegoßenes und weißgemahltes Brustbild, (H.) das Witt, des Witt, unter einem Dach einer kleinen Lauber-Hütte. Gegen über diesem Gebäude, ist eine Aleè, (D.) auf der Stelle, wo das vormahlige alte Pesthauß gestanden; Und, zu Ende der Aleè sind einige holzerne Gebäude (I.) vor das Leichen-Geräth, item, vor die Leichen, welche biß ein den 3. en Tag über der Erden liegen müßen; dabey ist auch ein Wach-Haus. Hinter des Pestvaters Hauß ist ein ander großes Gebäude, (K.) vor die inficirte Waisen-Kinder, welches

${ }^{76}$ Mopchen - nazwa cegieł holenderskich. 
nur eine große Stube, mit dicht rangirten schlechten Bett-Stätten hat. Wie dieses Hauß gleichsam auf einer besondern, durch Graben abgetheileten Wiese lieget: Also ist hinter demselben, ein, dergleichen mit Waßer umbfloßenes Feld, (L.) darauf die Todten aus dem Pest-Hause begraben werden; Auf selbigem ist jetzt ein Kohlgarten angeleget.

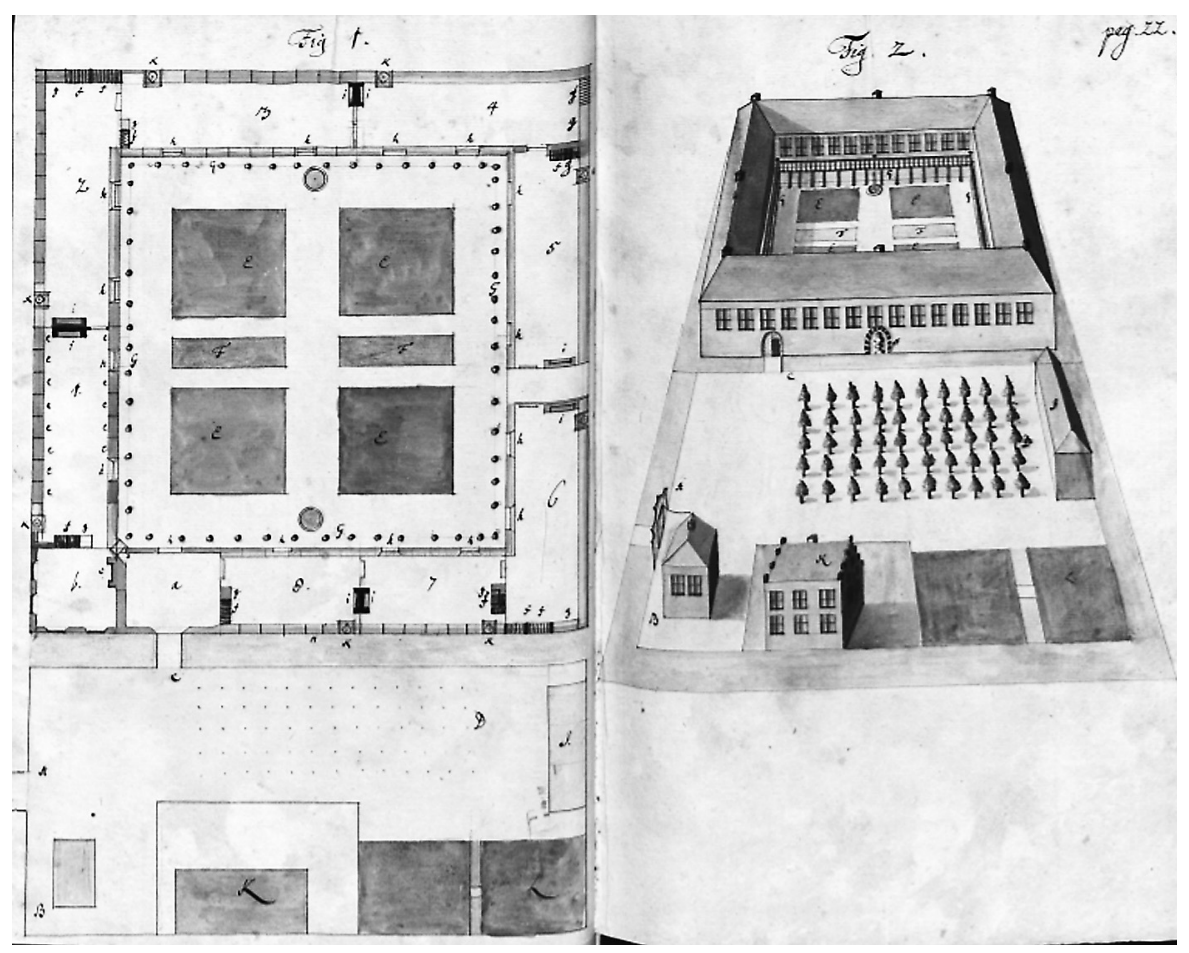

S. 21.

[Theatrum Anatomicum.] Jan. d. $6 .{ }^{77}$ war mit Hr. Gerlach im Theatro Anatomico, und ließ mir, praeliminariter, die, so hochberühmten Raritäten zeigen. Das Profil vom Gebäude, ist in Delices de Leyde, und großer, im Volumine Iconum Leidensium zu sehen. Nachdem ich alles in Augenschein genommen, finde darinne viel zu loben, aber auch viel zu verachten. Das Rawen Sachen, die Albinus, in Indice Supellectilis Anatoimcae Rawianae ${ }^{78}$, in 4 . to 1725 . beschreiben, meritiren

$771728 \mathrm{r}$.

78 Index supellectilis anatomicae: quam Academiae Batavae quae Leidae est legavit vir clarissimus Johannes Jacobus Rau, rogatu illustrissimorum et amplissimorum academiae istius curatorum et urbis consulum, Apud Henricum Mulhovium \& prostat quoque Franciscum Schuyl, 1725. 
den ersten Plaz, und sind mehr zu aestimiren, alß alles übrige. Unter den Sceletis humanis sind wenige recht rein, und ungestümmelt. Von Thieren ist nicht die Helffte, von dem, was zu Dreßden vorkomt. Es ist ein großer Fehler, daß man nichts ordentlich, und mit Verstand rangiret; Bilder, ausländische Kleider, artefacta, Gewehr, Instrumenta, etc. hängen neben- und untereinander: Viel ist gar nicht mehr käntlich: Viel Exemplaria besonders aus der Splanctinologie, und Angiologie, sind verderben, zum Theil auch gar schlecht praepariret. Von Myologicis ist nur ein, sehr elendes Subjectum. Was von Mumiis gezeiget wird, verdienet den Plaz, aber, das kleine Subjectum, woran man die weißen Zähne noch siehet, und, was man vor eine Princeßin ausgiebet, ist verdächtig, zum wenigsten, ist es keine rechte Aegyptische Mumie. Es wäre zu weitläuffig, alles allhier zu beurtheilen, was in den Delices de Leyde, a p. 83.-149. erzehlet wird. Man hat davon auch Indices in andern Sprachen, die bey den Theatro zu bekommen sind. Ich will demnach einen dergl. ad Acta nehmen, und zu demselben meine Kurze Remarqves machen. Überhaupt gefällt es mir nicht, daß man den Thesaurum Anatomicum, oder die Collectanea, ins Theatrum, wo Anatomien gehalten werden, und die Sache so offt von der Stelle gehoben werden müßen, transferiret. Der Platz ist viel zu eng, zu einem solchen Vorrath. Es ist nicht genug, daß man ein Hauffen Sceleta, und Naturalia zusammen treibet, sondern, man muß die Sachen in solche Ordnung stellen, daß man daraus Nutzen haben, und im kurzer Zeit viel durchsehen, und lernen könne; Kazen, Maüse, Frosche, Fische, Kinder, muß man nicht neben einander sezen. Wer Foetus sehen will, begehret nicht Frosche zu sehen, und, wer Frosche examiniren will, läßet sich an einem nicht genugen: ein dergleichen Stück, ist keins: Aber, wo eine Collection von dergl. Sachen zusammen ist, da ist der Nuzen davon offenbahr. In Summa, ein Naturalien-Cabinet einzurichten, erfordert so viel Kunst, alß eine Bibliothec anzuordnen. Dazu aber sind nicht alle Gelehrten aufgeleget; Viele favorisiren mehr dem Auge, alß dem Verstande, und machen aus nüzlichen Sachen Spielwerck; den besten Vortheil von dergleichen Anstelten, haben die Aufwärter, wie hie, des Schuyls seiner Frau, welcher man vor die Erlaubniß, einmahl ins Theatrum zu gehen, einen Schilling Holl. dergeben muß.

S. 30.

[Abermahlige Anatomie, bey Hr. D. Albino] D. 16. January, fieng Hr. D. Albinus abermahl an zu seciren. Das Cadaver war eine sehr vertrocknete Magd, von etwa 20. Jahren. Sein Vorhaben ist dabey, die 
Connexion von denen Contentis der dreyen Cavitäten, und zugleich von den Adern und Nerven zu zeigen. Was hievon merckwurdiges observiret, habe in Heisteri Compendio Anatomico aufzeichnet: Und, weil Hr. Albin. den Eustachium folget, und, bey jeder Demonstration allegiret, so habe zu des Eustachii Tabulis, ex discursu Albini, et collatione aliorum Autorum ab eodem allegatorum, eine Explication zugefüget, vermittelst welcher man mehr in den Tafeln finden kann, alß ungeübte, als sie gleich des Lancisii explication gelesen, darinn vermuthen sollten (...).

\section{§. 32.}

[Prof. Gravesand Lectiones, im Auditorio Physico.] D. 21. hörete, im herausgehen aus Hr. Dr. Albini Lection, daß Hr. Prof. Gravesand ${ }^{79}$, publicè Experimenta machen würde. Ich säumete nicht, den Auditoribus zu folgen, theils, den Hr. Professorem selbst, theils, die Einrichtung des Physischen Auditorii kennen zu lernen. Ich fand das Auditorium gleich an der Erden, wohl gelegen. Die Auditores sizen auf beyden Seiten, auf aufsteigenden Bäncken, in der Mitte stehet auf dem Plaz, die Antlia, und darauf fällt das Licht, durch ein hohes, großes Fenster, welches 10. Schuhe von der Erden, in der andern Etage ausgebauet ist. Die Antlia ist vertical, in einem Meßings-Parallelogrammate, ganz verschloßen, daß oben nichts alß die Stange, und, hinter ihr, das Creuz hervor raget. Das Meßinges Parallelogramma stehet auf einem hölzernen Postement, und machet, mit der Antlia, biß an das Creuz, eine höhe, von 5. Schuh, weßwegen der handlangende Knecht zum derhen, auf einer Treppe aufsteigen muß. Vor der Antlia, ist der Krahn, vermittelst einer perpedicularen Meßings-Stange, mit einem Manubrio oben zu regieren: und unten, von der Basi Antliae, gehet eine krumme Röhre von Meßing, unter den Tisch, zum Teller, unfern dem Teller, ist unter dem Tisch an der Röhre, ein Barometron, befestiget. Die Capacitè der Antliae ist, nach dem Augen-Maß, und, der Proportion der andern Theile, kleiner, alß die obliqvae Leupoldianae $^{80}$; Inzwischen ist der Effect davon sehr gut: wir ichs aus dem experimentiren erfahren habe. Hinter der Antlia, stehet an der Wand ein Schranck, darinn die Zubehör zur Antlia, Gewicht, und allerhand Instrumenta verschloßen werden können; Vor der Antlia, hänget an der Decke ein großer Wage-Balcken, und einige Hacke zu verschie-

${ }^{79}$ Willem Jacob's Gravesande (1688-1742) - matematyk i filozof natury, profsor matematyki i filozofii na uniwersytecie w Lejdzie.

${ }^{80}$ Jacob Leupold (1674-1727) - niemiecki fizyk, matematyk i twórca instrumentów naukowych. 
denen Experimentis. Hr. Gravesand ist ein munterer Holländer, etliche 30. Jahr alt, frey im Vortrag, in der Physic, und Mathematique wohl geubt, aber kein scharffer Logicus. In dieser Stunde tractirte Er, die Experimentae was negligent. Zum Beweiß, daß die Cohaesio corporum nicht allemahl $a b$ äeris compressione herkomme, machte er die Experimenta mit denen Haemisphaeriis Magdeburgicis. Erstlich halte Er zur Hand 2. große halb Kugeln von Meßing, nicht zu starck gegoßen, derer inwendige Rand wohl abgeschliffen war, selbige sezte Er schlechthin auf einander, und klebte über die Zuge rund um, BaumWax, welches nicht zu weich, aber sehr zeh und klebricht war. Darauf lies
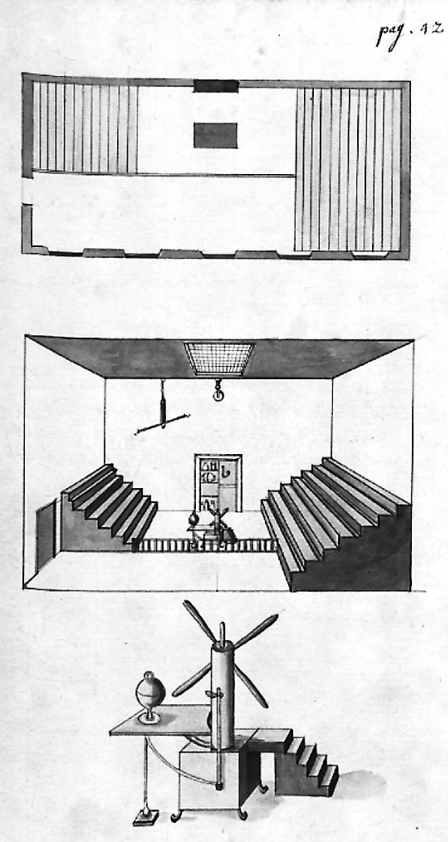
er die Kugel mit etlichen Zugen, etwa 8. oder 10. auslernen, wiewohl sie nicht rein ausgeleeret ward, maßen ich beym lezten Zug noch ein starckes Rauschen wahrnahm; Er gab den Diametrum der Kugel 8 1/4. Zoll an, die Schweren der, darauf druckenden Lufft, nach Proportion, 33, Schuh Waßer, davon jeder Cubischer Schuh 55. lb. ${ }^{81}$ wiegen solte, auf 2000. lb. Es wurden aber die Kugeln von 800. lb. auf der davon abhangenden Waag-Schale, innerhalb einer dreybeinigten Stellage, von einander gerißen: welches zwar eine Drückung der Lufft bewiese, aber nicht mathematisch determinirete. In dergleichen Experimentis, wenn sie Nuzen in scientiis haben sollen, muß alles genau berechnet, und gegeneinander gehalten werden, e.g. hie hätte 1.) die Area circuli, maximi, Sphaerae, 2. soliditas Cylindri, cujus basis, areae ante dicta, et altitudo columnae aqvae, 32. pedum Rhenanorum aeqvalis est, 3. Gravitas ejusmodi cylindri aqvei, accurat bestimmet, und dann, so viel gewicht, alß das Facit angezeiget hätte, angehangen werden sollen. Wenn accurat in allem verfahren wird, müßen die Kugeln noch ein mercklich mehreres halten, weil das Wax an sich eine großte Festigkeit verursachet. Zweytens, hatte Er, einen kleinen,

${ }^{81}$ Lb (libra) - jednostka masy, funt. W Niderlandach Północnych do XIX w. jeden funt ważył - w zależności od miasta - od 433 do 498 gramów. 
hohlen Meßings-Cylinder mitten durch getheilet; die Höhe, und der Diameter waren etwa 4. Zoll: diesen ließ Er auch evacuiren, und riß ihn mit 50. lb. von einander: welches nichts mehr, alß das vorige bewieß. Endlich, hatte er, einen gleich großen Soliden Meßings Cylinder getheilet, geschliffen, und mit Heiß Wax zusammen gefüget, selbiger hielt über 1000. lb. Weil nun der hohle Cylinder, der von Lufft zusammen hielte kaum 50. lb. trug, dagegen der Solide über 1000. wollte Hr. Gravesand daraus gründlich erwiesen haben, qvod äeriis compressio non sit cohaesionis causa in corporibus. Die Conclusion ist zwar richtig, und aus andern Gründen gnug bekannt. Weil aber der Hr. Gravesand weder die Haemisphaeria, noch die hohlen Cylinder recht ausgeleeret, dabey auch kaum Experimenta machen wird, da alle Lufft, durchaus weggenzogen, und also alle elasticiè zwischen zweyen Cavitäten gehoben werden kan: so bleibt bey diesen Experimentis noch der Zweifel, ob nicht, wenn alle Lufft zwischen den Halbkugeln weggeschaffet werden könte, dieselbe so zusammen halten möchten, alß wenn zwey Plana aud einander gefuget werden, nicht mit Talch oder Wax, sondern, mit warmen Oel, daraus alle Lufft getrieben worden.

\section{S. 34 .}

[Des Mons. de la Curten Garten ${ }^{82}$.] D. 22. January, machten wir bey Mons. Coulet einen Anfang zur Engeländischen Sprach. Nachmittag, da ein seltsamer Sonnenschein, mit wenigen Frost einfiel, beliebten wir Hr. ${ }^{\mathrm{n}}$ de la Courten Garten, bey der Harlemmer Porte zu besuchen. Hie findet man keine kostbare Gebäude, Statuen, große Allees, künstliche Blumen-Felder, sondern wohlangelegte Treib-Häuser, Glas-Cassen, Mist-Bethe, Hecken, Zäune, und dergleichen. Ich will, was ich in diesem seltsamen Garten abgesehen, nach der Reihe umbständlich erzehlen. Der große Garten ist gleichsam in verschiedene Wiesen, vermittelst vieler, durchlauffende Graben, getheilet. Von hinten, da man über den Thamm hineins komt, ist ein großes Feld mit Bethen, zu allerhand Küchen-Gewächß, aptiret. Umb die Winde, oder auch, nach Beschaffenheit der Gewächße, die übrige Same abzuhalten, sind Ulm- und Espen-Bäume, in Reihen, und anderwerts nidrige Hecken von Else gepflanzet. In einigen niedrigen Glaß-Cassen, A. wolten Anemone und Narcißen bereits blühen, das Coclamen Aleppicum aber war

82 Pieter de la Court van der Voort (1664-1739) - niderlandzki kupiec i ogrodnik. Jego ojciec Pieter był pionierem uprawy roślin w ocieplanych szklarniach. Inne ogrody lejdejskie opisano w $₫ 35$ i 38. Dlatego że w ww. relacjach nie skupiano się jednak na roślinach i sposobach ich uprawy czy „botanicznej” aranżacji przestrzeni, zostały one pominięte w prezentownaym wyborze. 
schon in wollem Flor. Die Feigen Bäume stunden frey in der Erden, nur ihre Äste waren oben zusammen, und, nach angesetzter Figur B. zwischen Stangen gebunden, daß man bey einfallenden Frost etwas drüber hängen könte. Auf einigen Horizontal Bethen lagen Fenster, auf 4. angeschlagenen Pfahlen, worunter allerhand früher Sallat schön angefangen war. vid. C. Wo der Garten einen Zaun brauchet, ist einer Mauer, von Holländischen Klinkers gezogen: An selbiger sind allerhand Glaß-Cassen angebaudet, worunter der schönste Wein, auf alle Monath im Jahr, getrieben wird. Wo er früh kommen soll, z.E. auf den April, sind die Glaß-Cassen zu hizen, Fig. 1 Anderwerts sind sie nur bloß mit Fenstern zu versezen. Nirgends siehet man etwas mit Stroh, oder mit Mist bedeckt ${ }^{83}$; bey Tage, stehen, wo es nicht gehizet wird, die Fenster offen. Im großen Gewächß-Hause, Fig. 3. welches auch nicht geheizet ward, war eine kleinstammige oranjerie, von allerhand raren Sorten, unter andern, eine sehr curieuse Art Juden-Apfel, oder Citronaten, welche groß, knollicht, länglicht, und, alß doppelt- oder dreyfach ist. Item, eine Türckische- und eine Engländische Sorte, von bunten oranien. In der andern Helffte des
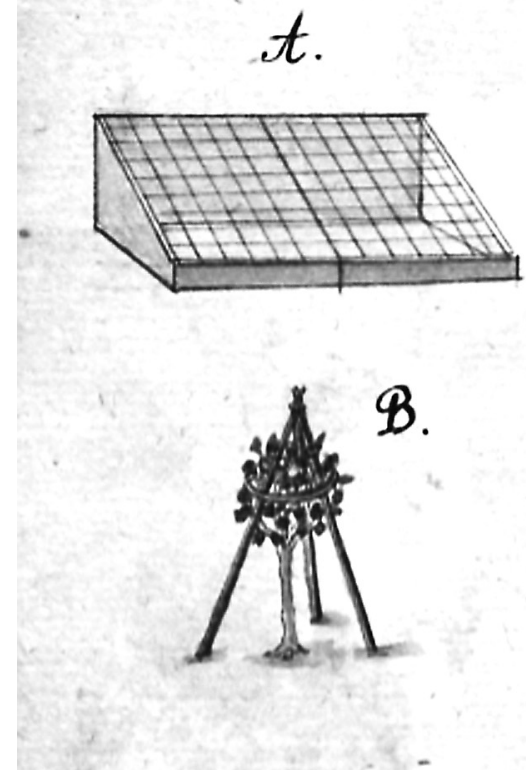
Gewachß-Haußes, A.C.D. Fig. 3.

${ }^{83} \mathrm{~W}$ taki sposób z kolei uprawiano rośliny w ogrodzie medycznym uniwersytetu lejdejskiego. Zob. K. Pękacka-Falkowska, Johann Philipp Breyne i jego ogrody: hortus vivus i hortus siccus, [w:] Historia - klimat - przyroda. Perspektywa antropocentryczna, Toruń 2018, s. 217-228. 
ist das Treibhauß sehr artig, zur Cultur der fremden Gewächße eingerichtet: wir solches durch beyliegenden Riß anzeige. In dem hontern Gemach, A.E.F.B. Fig. 4. welches nicht gehizet wird, waren keine rare Gewächß; aber, in dem Vordern Departament, A.C.D.B. Fig.4 welches sehr heiß war, stund eine ungewöhnliche Collation, von bey nahe 200 Stücken Ananas, dreyerley Arth, darunter doch keine jetzt Frucht gesezet hatte. Zur Seite der Treib-Häußer, sind tieffe Glaß-Cassen, á.b. Fig. 7. die Ananas zur SommersZeit, mit Mißt zu treiben. Dieselbe sind in einem niedrigen gemauerten Zaum, a.b.c.d. eingeschloßen, an welchem der Wein, und die Zwergbäume gepflanzet stehen. Im Lande stehet nirgends zwischen den Bethen ein Baum, sondern es werden alle an die Wände gestellet: Wie ich mercke, mit besondern Vortheil, davon ich folgends melden werde. Der vordern Plaz, Fig. 6. wo die rechte Entreè A. vom Garten ist, hat in der Mittte ein großes rundes Basin, B. vier Stuffen tief, mit Klinkers gemauret, in der Mitte eine Röhre zur Fontaine; Rund umb, sollen zur SommersZeit die oranjen Bäume gesezet werden. Umb das Bassin ist ein breiter Gang, C. mit einer hohen Hecke, D.D.D. von Heynbuchen eingefaßt, welche die zwey gegeneinander gelegen Thor-Wege, A.B. schneiden. Zur Seite ist der Thurm zum Waßer-Schaz, mit Clematis bekleidet. Die Kostbarkeit dieses Gartens besteher also in dem Apparatu Horticulturae artificiosae, rare Blumen, und schöne Fruchte, frühe und spät, zu

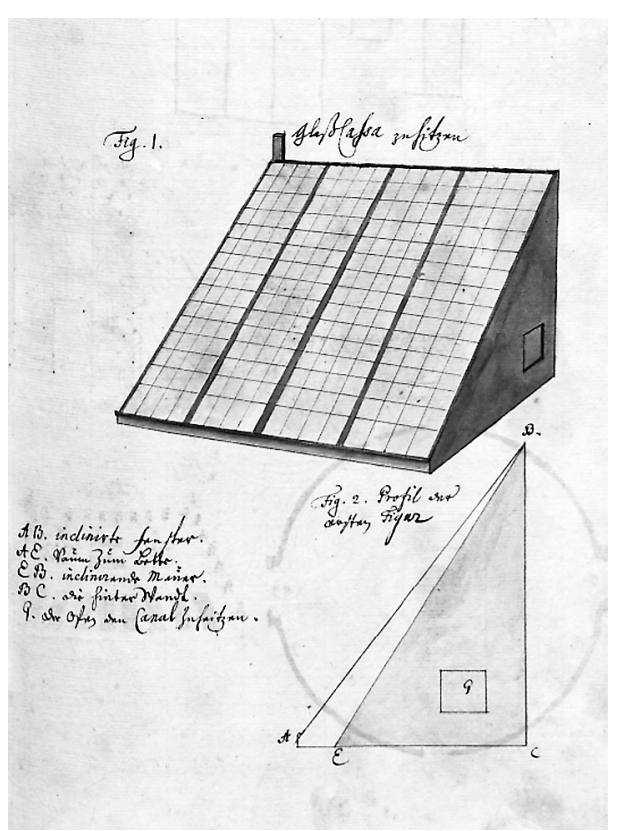
selbstbeliebten JahresZeit zu haben. Es ist darinnen nicht ein Blat zu Kauff, sondern, alles zum Plaisir des reichen Eigenthumers. Im Vorjahr sollen ungewöhnliche Species, von Hyacinthen, und Tulipanen, etc. hie $\mathrm{zu}$ bewundern seyn. An der Thur der Gewächß

Fig. 1. GlaßCassa zuhitzen Fig. 2. Profil der ersten Figur

AB. Indinirte Fenster.

AE. Raum zum Bette.

EB. indinaende Mauer.

BC. die hinter Wand.

G. der Ofen den Canal zuhitzen. 
Stube ist ein Hyacinthen Stengel nach dem Leben, mit Oelfarb abgemahlet, daran die 14. Weiße Blumen, die größeste Leucoja übertreffen. Ich hätte bald vergesen, zu gedancken, daß, bey der jetzigen Winter-Zeit, denen übrigen Gewächßen, außer denen Ananas, nicht mehr, alß Tages-Licht gegeben werde. Die Sonne wird durch die Zugedncktendächer mit Fenster-Laden abgehalten. Kurz: bey allen Gewächßen, wie ich mercke, vorhütet man nur den Frost, und, so lange derselbe nicht $\mathrm{zu}$ befurchten, gönnet man ihnen freye Lufft.

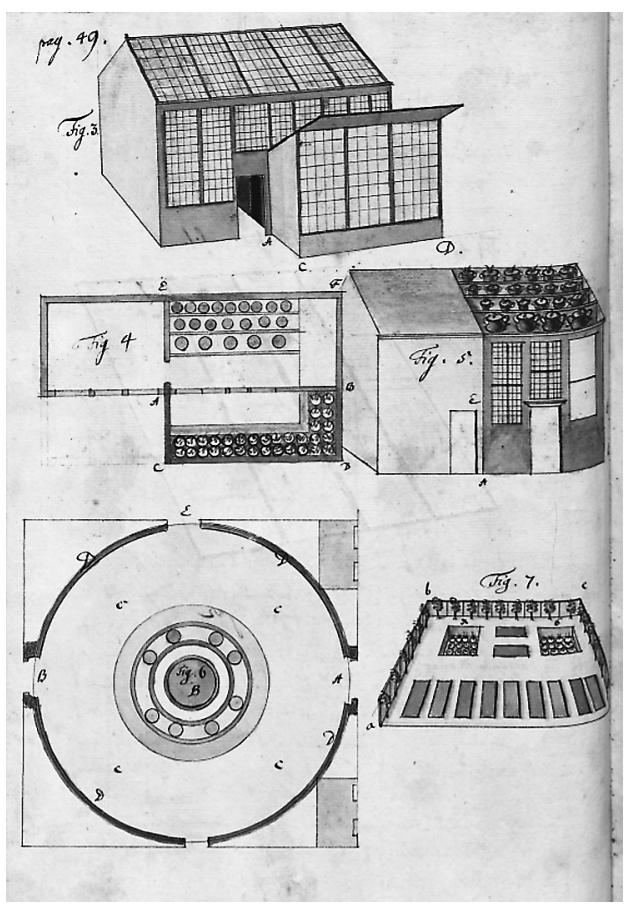

\$. 39.

Deßelben Tages ${ }^{84}$, gegen die Nacht, fuhr umb 17 Uhr, mit Hr. Schreibern nach Amsterdam, der Auction des verstorbenen jungen Ruyschen beyzuwohnen. Ich war müde, und hatte schlechtes Wetter, in der Nacht mich unbzusehen, demnach passirt die Zeit biß gegen den Morgen, mit schlaffen.

[D. Bohlii curiosa Anatomica, zu Amsterdam] D. 29 Jan. kahm um 7. Uhr, Morgens, zu Hr. D. Bohlio ${ }^{85}$, in Amsterdam. Ehe er mit mir nach der Auction gieng, besahe ich seine collectanea Anatomica, die er vom seel. jungen Ruyschen bekommen. Selbige bestehen in verschiedenen, mit roth Wax ausgesprizten Membranis, und Stücken, von kleinen Cadaveribus humanis. Das remarqvableste davon ist ein Kinder-Kopff, mit geöfneten Cranio, eine mittelmäßige Hand, ein Stück von der Leber, ganz fein alles ausgesprizt, und trocken conserviret; Ein kleiner Fuß, eines reiffen Embryonis, von Menschen, sehr fein, und ganz roth gefüllet, in liqvore. Ein Stück von der membra-

${ }^{84} 28$ stycznia $1728 \mathrm{r}$.

85 Johann Christoph Bohl (Bohlius, Bohle) (1703-1785) - niemiecki lekarz, absolwent uniwersytetu w Lejdzie, od 1726 r. współpracownik Frederika Ruyscha. 
na. dartos, wie verwickeltes Haar aufgeblasen. Psevdo-membranae, über einem bircken Rühtlein, von Menschen-Blut gemacht, in Spiritu. Außer diesen Anatomicis, hat Hr. Bohlius auch eine feine Collection, von Indianischen Insectis, welche eine beßere Wartung, alß in seiner confuten Haushaltung meritiret. Seine kleine, anatomische, und medicinische Bibliotheqve hat, viel rare Editiones von Büchern.

[Auction der Raritäten von Ruyschio Jun. zu Amesterdam nachgelaßen.] In der gedachten Auction, waren der Catalogus in Volum. Catalog. in 8. . $^{\text {vo }}$ morin $^{86}$, beylieget, verkauffe man bey unserer Anckunfft, die Animalcula, in Spiritu conservata, zu 10. Stück auf eins. Die große Collection bestand in Fischen, davon ich vor Hr. Secret. Klein nach Danzig, die, Ihm fehlende Supplementa wehlete. Hiernechst erhielte auch die rariora marina, alß: Pennum marinum, Loligines, Solenes, Alcyonium, Palmam marinam etc. Von Quadrupedibus, muste den Embryonem eines Stachel-Schweins, der so groß, alß eine kleine Kaze war, von 20. Fl. Holl. und, einen ungewöhnlichen Lacertum, der so groß, wie der Crocodilus terrestris, oder Lacertus maximus, aber, von Gestalt dem Chamaeleon ähnlich war, vor 30. Fl. Holl. am Hr. ${ }^{n}$ Seba $^{87}$ fahren laßen: diese war auf diese Curiosa so vergicht, daß er, eines davon, nicht vor 100. Fl. Holl. aus seinen Händen wolte kauffen laßen. Die übrigen Sorten, von Schlangen, Thieren, und Vögeln, waren zu Danzig schon bekannt: weßwegen nur nach den Defecten strebete: welche, hie, accurat zu Specificiren, die Gelegenheit nicht habe, nachdem die Sache in der Eil zusammen packen, und, in Amsterdam zurück laßen müßen. Außer denen Animalibus, waren auch 2. große eichene Cabinet, mit allerhand Miscellaneis. In einem waren schöne vegetabilia exotica, alß Fructus, Semina, Gummata, Ligna, und, so zu sagen, die ganze Materia medica, vollständiger, alß ich sie im vegetabilischen Cabinet zu Dreßden gesehen; dabey lagen allerhand andere Naturalia, von Marinis, und Petrefactis. Ich hätte die Collection gerner gehabt; Weil aber Hr. Seba darauf boht, und nicht davon abstehen wolte, mußte es ihm von 70. Fl. Holl. zuschlagen laßen. Dagegegn, erhielte das andere, welches an Conchyliis, Stellis Echinis, und einigen andern Collectaneis praevalirte, vor 40. Fl. Holl. die übrigen kleinen Cabinetyen, mit Engelländischen, Schweizerischen, und andern Petrefactis, woran von keiner sonderlichen Consideration. Von Anatomiosis war allhie, außer einige Partibus Animalium, nichts zu sehen. Die Zeit

${ }^{86}$ Druga kolekcja Ruyscha została skatalogowana w latach 1724 oraz 1728 przez niego samego i Abrahama Vatera.

${ }^{87}$ Albertus Seba (1665-1736) - niderlandzki aptekarz, zoolog, kolekcjoner. 
verlieff mit dem Einpacken der Sachen, daß ich mich von dieses mahl in Amsterdam nicht umsehen konte. Es war bereits 3. Uhr Nachmittag, da ich den 31. Jan. über Harlem wieder nach Leiden kehrete.

\section{\$. 41.}

[Hr. Albini geendigte Demonstrationes.] D. 2. Febr. schloß Hr. D. Albinus seine Demonstrationes anatomicas, in welchen er die Splanchnologie, Angiologie, und Nervologie in Trunco et artubus demonstriret. Das übrige sezet er in die folgende Sectionem et Demonstrationem Chirurgicam, item, in die Lectiones Physiologicas, aus. An dem bißherigen Subjecto, war nichts außerordentliches zu observiren.

\section{S. 45.}

[Winter-Pflege der Gewächße, im Horto medico.] D. 7. Febr. gieng Nachmittag, in den Hortum Medicum, umb zu sehen, wie man jetzt, da es etwas frieren wolte, der Gewächße pflegete. Im Lande waren die ausländlischen Wurzeln, mit gläßernen Melonen Kästlein bedeckt. Siede Kästen werden in ein eisern Gestell befestiget, wie die Fenster in Wind-Eisen, damit sie nicht der Schnee, oder Plaz-Regen zusammen schläget. Dergleichen Gläsernen Glocken oder Decken, sind im Garten über 100. Stück. Wenn der Frost starck ist, werden einige Blätter, oder etwas Stroh, auf die Wurzeln, unter die Glocken, geworffen. Das übrige im Feld, und an den Wänden war alles bloß. Nach der Mittags Seite $\mathrm{zu}$, ist die Helffte vom Garten, mit einem niedrigen Gegitter verzäunet: und, daselbst stehen, innerhalb dem Gegitter, die Pflanzen, so noch angezogen werden, und, hoch nicht in die Ordnung nach dem $\mathrm{Ca}$ talogo gesezet sind. Das große Sommer-Hauß war, bloß von der Sonnen, recht warm; da-
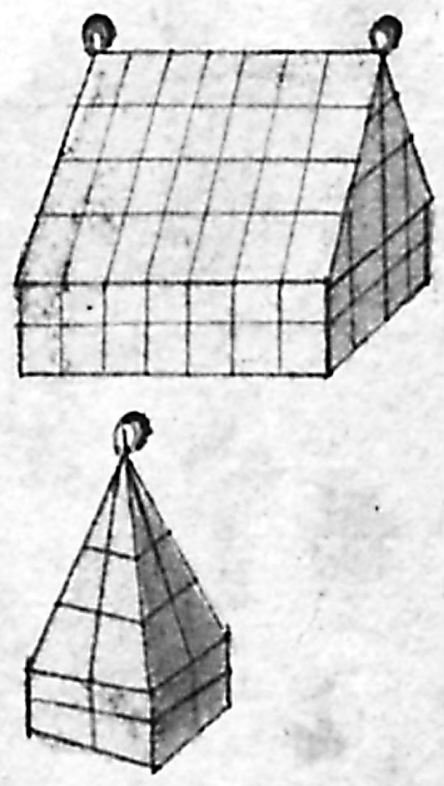
rinne fand nichts, alß einen Tithymalum, eine Conizam und blühen. Draußen, unter den Fenstern, blühete in der Glaß-Cassa, ein rothes Cyclamen hiemale; von denen übrigen 6. Sorten aber, wolte eine weiße zur Blüthe treiben. In denen beyden anderen, nach Morgen liegenden Treib-Häußern, die mit Souterrains gehizet werden, sahe, am den Africanischen und Americanischen Gewächßen keine Blüthe, außer, daß einige Ficoides und kleine Alöes trieben. In dem einen Zimmer hatte Hr. Boerhaven die Semina rangiret, und eine Specification seiner Corespondenten zur Hand geleget, an welche er Semina zu senden hatte; Unter diesen fand auch: Behringer ${ }^{88}$, zu Würzburg; die übrigen waren mir unbekannt. Im Saamen-Cabinet waren die Fächlein mit gleich großen papiernen Behältnißen, von 4. erley Farben, ausgekleidet. Die Plantae perennes hatten weiß Papier; die Biennales, blau, und die annuae, rothe Kästlein; zur Distinctione Specierum, waren schwarzen Fächlein dazwischen gestellet. Ich fragte: Ob der Arbor Tulipanifera Hoffnung zur Blüthe gäbe? Und hörete zur Antwort: daß, so ansehnlich der Baum ist, so habe er dennoch niemahls geblühet; Es scheine auch, alß wolle er in Holland keine Blüthe treiben, weil mehrere Liebhaber solcher Bäume, vergeblich, biß daher, auf die Blüthe gewartet (...).

\section{S. 61.}

[Adriani Royen Doctor-Promotion.] D. 23. Febr. war eine DoctorPromotion, in Medica. facultate. Der Candidatus hieß: Adrianus van Royen $^{89}$, ein geschieckter Mensch, von etl. 20. Jahren, aus einer hiesigen vornehmen Famille. Sein Vater ist in hiesigem Magistrat gewesen. Sein Bruder ist Secretarius Curatorum Academiae, und hat des, hie hochangesehenen Bürgermeisters von der Berg Tochter. Boerhaven will dem jungen Menschen wohl, und hat eine einige Tochter, die großes Geld dermahleins zu hoffen. Nach der Promotion gehet der neue Doctor nach Franckreich, die Botaniqve zu excoliren. Hieraus machen einige des Prognosticon, daß dieser von Royen dermahleins Boerhaven, wo nicht werde adjungiret, gewiß nach seinem Tode succediren werde: Obgleich D. Albinus, zur Professione Botanices große Neigung zeiget. Die Disputatio inauguralis, de Anatome, et Oeconomia Plantarum, war dem Hr. ${ }^{\mathrm{n}}$ Boerhaven, mit einer schönen Latinischen

${ }^{88}$ Johannes Bartholomäus Adam Beringer (1670-1738) - niemiecki lekarz, profesor medycyny na uniwersytecie w Würzburgu.

${ }^{89}$ Adriaan van Royen (1704-1779) - niderlandzki medyk i botanik. Zanim odbyła się jego dysputa pro gradu, 14 sierpnia 1727 r. omawiał aforyzm 3 i 4 z VI ks. Aforyzmów Hipokratesa. Universitaire Bibliotheken Leiden (dalej jako UBL), ASF- 415, s. 281, 283. 
Elegie dediciret, die Ausführung des gedachten Arguments, ist sehr wohl gerathen. Was bißher von Malpighio ${ }^{90}$, Grewio ${ }^{91}$, und andern, mir verdrüßlicher Weitläuffigkeit, und, ohne Ordnung, von dieser Materie vorgetragen, ist hie mit einem deutlichen, und fleißenden Styl, in ein anatomisch Physiologisches Systema zusammen gezogen, woran ich nichts desiderire, alß, daß nicht die Autores gehörig sind allegiret worden, aus deren Erfahrungen der Autor seine Säze gemachet. Mir komt aber diese Arbeit alß ein Grund-Riß eines größen Wercks vor, woran der Autor zu arbeiten Lust bezeiget. Der Actus disputatorius, gieng umb 10. Uhr, Morgens, im großen auditorio an. Zu Anfang war Niemand, dem Hr. Boerhaven, alß Promotor, zugegen. Nachdem der Doctorandus von der untern Cathedra mit bloßem Haupt und kurzen Worten, libertatem disputandi gebethen; So meldete sich der erste opponens auf der Banck, vor dem Catheder, bath auch, mit 2. oder 3. Worten Erlaubniß, zu reden, vom Promotore, und proponirte gleich das Argument wieder die allegirten Worte. Wem einmahl darauf geantwortet worden, schritt der opponens zu einen andern Argument. In solcher Arth opponirten in einer Stunde 3. Studiosi, und ein Candidatus Medicinae, alle, mit entblößtem, und endlich, ein junger Doctor, mit gedecktem Haupt, /: weil Promoti das Jus pilei, auch so gar, in Foro litigioso coram Magistratu haben :/ Mittein im Argument schlug die Uhr 11. worauf, da es der Pedell vor dem Catheder meldete, der opponens gleich aufhörte; der Respondens dankte darauf, mit wenigen und gemeinen Worten, denen Professoribus, pro praesentia., dem Promotori, pro libertate concessu. disputandi, denen vornehmen Hospitibus, pro praesentia., und dem $\mathrm{Au}$ ditorio, und den opponenten, pro attentione et oppositione. Unter dem Disputiren, welches do still und leise fortgesezet ward, daß man in der 3. ten Banck vor der Catheder fast nichts hören konte, wartete der Pedell vor dem Auditorio, und so offt ein Professor in seinem Talar ankahm, gieng er biß an die die Banck vorher, mit seinem großen klingenden Sorgter. Nun hatte diese Pedell keinen schwarzen Habit an, sondern er war nur gewöhnlich licht gemäntelt. Nach der Disputation giengen alle Professores nach einander, und endlich auch der Doctorandus hinauf in die Promotions-Stübe, allwo über seine Capacitè geurtheilet, die vota colligiret, das Promotions-Geld gezahlet, und, der Titel des Doctoris dagegen ertheilet wird (...).

${ }^{90}$ Marcello Malpighi (1628-1694) - włoski medyk i historyk naturalny, zainteresowany m.in. botaniką.

${ }^{91}$ Nehemiah Grew (1641-1712) - angielski medyk i botanik. 
§. 65.

D. 27. Febr. besuchten unß Hr. Hunter, und Hr. D. Bohlius von Amsterdam, und, da Hr. Gerlach ihm, bereits vorgenommen, nebst Hr. Dilger dahin zu gehen, umb einige Wäsche zu besorgen, machten sie mit Hr. Huntern Compagnie, und fuhren den 29. Nachmittag, mit einem Cariol dahin. [Engländischer honetter Tisch-Compagnon] Daßelben Tages gieng auch dahin mit der Schuite, ein Engelläder, welcher mit und einige Wochen im Guldenen Löwen gespeiset. Selbiger kahm anfangl. an den Tisch recht schlecht und still aufgezogen, redete in einigen Tagen nicht ein Wort, biß er uns kennen gelernet; Nachmahls fieng er an, die ganze Mahlzeit durch, de Moralibus et Politicis, besonders auch von Staats-Sache, hochstvernünfftig, mit großter Französischer Beredsamkeit zu raisoniren, zu vielem Plaisir der gantzen Tisch-Compagnie. Er war von Statur und Alter mittelmäßig, schön von Gestalt, und sehr angenehm und douce im Umbgebung. In seiner, und des Dieners schwarzen Kleidung, imitiret er eine Hoff-Trauer. Ließ weder Uhr noch Ring, noch Tabattier, noch das geringsten von Kostbarkeiten sehen, obwohl er in der Suite, und beqvemlichkeit ihm nichts fehlen ließ; Im Spielen und Conversation zeigte er keinen Eigennutzen; von seinem Nahmen, Geschlecht, und Stand, gab er uns nichts zu erfahren, alß, daß er von Jugend auf, in militarischen Diensten gestanden, ein Capitain unter den Engelländischen Dragonen gewesen, und, Gelegenheit gehabt habe, in Politische Affaires mit einzusehen. Er war des D. Boerhawen wegen nach Leiden kommen, umb, von Ihm ein Consilium Medicum, über sein 3.jähriges Blut-Speyen einzuziehen, muste aber ungeholffen wegreisen. Hr. Boerhaven hatte ein Paar Sälblein mit Milch einzunehmen, von Gummi opapanacis, Ol. Therebinthini, Succo Glyzirrhzyae, und Succini, nebst einen äußerlichen Pflaster, verordnet: aber es wolte nicht anschlagen; Am besten befand sich der Patient, nach dem Einnahmen des Spermatis ceti. Durch den teutschen dieser dieses Chevaliers erfuhren wir, daß sein Hr. Vater ein Ambassadeur gewesen, und der Herr, nachdem er seiner Compagnie verkauffet, jetzt nach Herren Hausen gehen, und daselbst den König von Engelland abwarten wolle, von dennen gedachte er auf Berlin zu gehen. Laut seinen Discursen, war erwehnter Chevalier des Reisens sehr gewohnt, maßen er Holland verschiedene mahl passiret, und Italien, Franckreich, Deutschland, durchreiset. Weil hörete, daß wor resolviret wären, nach Engelland zu gehen, offerirte er uns eine Recommendation an seinen Medicum, um guten Freund, D. Thissier, der uns bey Hr. 
Sloan $^{92}$ Addresse verschaffen würde, und ließ un $ß$ an selbigen einen Brief, der wir mit Danck von ihm annahmen.

\section{§. 73.}

D. 6. Marty, überfiel bey Tisch, den Hr. Gerlach ein Fieber, welches wir anfänglich von ein Fluß-Fieber ansahen. Er recolligirte sich nach selbiges Tages, nach wenig Stunden, und resolvirte, Morgen zur Ader zu laßen, weil er sich, wegen Vollblütigkeit nicht zu wohl befand. D. 7. War Hr. Gerlach recht unter, und bediente sich des Aderlaßens am Fuß. Unsere gesamte Reisen Compagnie wollte mit Blut laßen; da wir aber den chirurgen beym ersten Aderlaßen des Hr. Gerlachs, am Fuß, etwas furchtsam sahen, blieb dieses Vornehmen annoch aufgeschoben. Hr. Diliger aber ließ einen andern Chirurgum gegen Mittag holen, welcher ganz glücklich Ihm, am Arm, die Ader öfnete. D. 8. Mart. $\mathrm{Da}$ aus Hr. Boerhaven lectione Chymica nach Hause kahm, fiend hr. gerlach eben umb die vorgestriger Zeit, wieder am, zu schuttern, welches mich abermahl sehr verschrecket, daß die folgende Nacht nicht schaffen konnte, und, ein hieziges Fieber besorgete. Demselben vorzubeugen, ließ morgendes tages, al $ß$ den $9^{\text {tn }}$ Marty, zur Ader, wiewohl mich darauf nicht zum besten befand, weil ich mich etwas in die Kalte Lufft ausgemachet, umb nicht die angehende Demonstrationes Chirurgicas des D. Albini zu versäumen.

\section{S. 74.}

[Hr. Boerhavens Lection: de rebus Chymicis.] Es dürffe mir die Zeit fehlen, mehrmahlen den Hr. Boerhaven in Chymicis zu hören, und von seiner Methode, und Anstalt in folgenden zu gedencken; demnach will allhier das wenige, so ich observiret, mercken.

[Auditorium Chymicum.] Hr. Boerhaven ließt, gewöhnlich, im $\mathrm{Au}$ ditorio Chymico, wohin man durch den Hortum Medicum, aus seinem Hause gehen kan. Die Einrichtigung deßelben, ist, ex Schemate zu ersehen. Dieses Jahr profitiret Er, die Chymie bloß, publicè, und handelt darinn, von einigen besonderen, und neuen Experimentis, und Hypothesibus, dadurch Er die Chymie zu mehrerer Gewißheit bringen will. Vom vorigen Jahr war noch etwas übrig, de menstruis, da Er dem besonders gewiesen, daß die Olea, sub certo gradu caloris, die Metalla und Mineralia solviren. Nun fänget Er an, die Materiam:

${ }^{92}$ Hans Sloane (1660-1753) - angielsko-irlandzki lekarz, historyk naturalny i kolekcjoner, początkowo sekretarz, następnie prezydent Royal Society. Więcej o nim zob. J. Delbourgo, Collecting the World: The Life and Curiosity of Hans Sloane, London 2017. 
de Salibus. In der Stunde, da ich Ihn hörete, gab er Definitionem, et distributionem Salinum. Er nennet alle Glebas Saltz, welche durch den Geschmack sich unterscheiden, im Waßer auflösen, und im Feuer schmelzen laßen. Der Unterscheid darunter bestehet darinne, daß einige sind: Alcalina, einige Acida, und einige Neutra. Die Acida sind fast alle Liqvida: Oleum Vitrioli in frigore concrescit, sed levi calore iterum solvitur. Die Alcalina sind alle Fixa, d.i. sie brauchen zum Schmelzen einen stärckern Gradum ignis, alß das Sal Ammoniacum. Unter den Salibus acidis sind einige vegetantia nativa fermentantia, alß: die Säuer, in Französischen Wein, welcher mit Schwefel, und verschloßenen Gefässen, in Fermentatione gleichsam gehemmet wird, daher er leicht bey der Lufft jähret. Einige sind Fermentata, alß: der Rheinwein, welcher ausgejohren hat, ehe er in Fäßer gefüllet wird; daher pflegt selbiger nicht, ex iisdem Principiis, zu jähren. Einige Acida vegetantia kommen ex ussu, e.g. die Lachryma ligni ardentis, oder titionis, welches ist der Safft, der aus dem naßen Holtz, auf einer Seite ausgrillet, wenn man es auf der andern Seite anbrennet. Andere Acida vegetantia kommen ex destillatione, e.g. wenn man geraspelt Holtz in einen Kolben verschließet, träuffelt bey der Wärme ein Spi-

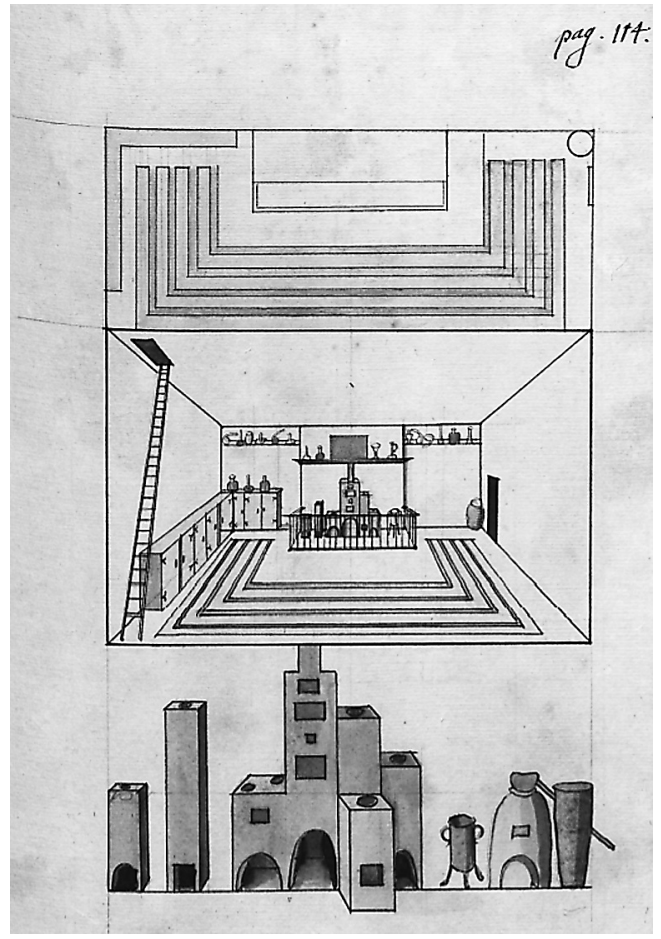
ritus ab. Es giebt ferner, Acida fossilia, ó.) Sal vagum in fodinis, $\beta$.) Acida fossilia accensa, alß Schwefel. V. ) Acida fossilia destillata, e.g. ex Sulphure, vitriolo, Alumine. Unter die Salia neutra gehören, Sal marinus, Borax, Nitrum, Sal gemmae, Sal fontanus, Sal ammoniacus nativus, s. Cyrenaicus. Außer diesen Salibus, giebts auch einige composita, welche aus verschiedenen, vorgedachter Salium gemischet sind. In dieser Lection macht $\mathrm{Hr}$. Boerhaven einige Digresiones, de definitione corporis, de qualitatibus sensibilibus, und vermeinete, daß, weder Cartesius, noch Jemand, 
von denen übrigen Philosophis, sich darinne selbst verstanden. Man schmeckt zwar das saure, aber, wer kan die Säure erklären, oder, derselben Unterscheid bestimmen? Hierinnen sind $\mathrm{Hr}^{\mathrm{n}}$ Boerhaven die Leibnitianer nicht entgegen; denn, selbige bekennen auch von den Qvalitatibus sensibilibus nicht anders den klaren Begriff zu haben, welche annoch keine Definition ausmachen; Indeßen ist genug, daß wir uns untereinander verstehen, wenn wir sprechen: dieses ist vitriolisch, Eßig sauer, und so weiter. Einige composita sind zu subtil vor unsere Sinne, alß daß wir ihre ingredentia und partes mögen erkennen; bey denselben bemühen wir uns vergeblich, ihr Wesen ins besondere zu expliciren. Daraus folget aber nicht, daß wir nicht von Cörper überhaupt, einen deutlichen Begriff haben, noch davon, eine richtige Definition geben können. Es kam dieselbe von groben, sichtbaren, und deutlich empfundenen Cörpern abstrahiret werden. Wir könten auch von den Corporibus ins besondere viel deutlicher reden, wenn wir ordentlicher dieselbe einsehen, und, die Ähnlichkeit derselben, nach den bekantesten Dingen bestimmen möchten. Z.E. Wenn ich einem Kupfer-Waßer verlege, und zu schmacken gebe, und spreche, was also schmecket alß dieses, das wollen wir ins künfftige vitriolisch nennen, so bleibt im Reden hier Undeutlichkeit; der übrige Unterscheid, läßet sich durch andere dergl. Differentias bestimmen. Aber, es ist ein großer Unterscheid, in Erfahrung, und im raisonniren geübet seyn. Man muß Hr. Boerhaven dieses laßen, daß er in Chymicis sehr ordentlich, scharffsichtig, und behutsam im experimentiren ist; Auch fließen seine Conclusiones immediatae gar wohl ex experimentis: Aber, so bald es ad universalia komt, mercket man den defectum Philosophiae, der den Holländern fast durchgehends gemein ist, maßen sie, außer der experimental Physic, wenig taugliches davon hören. Es sey aber, daß Hr. Boerhaven das Raisonement in Chymicis nicht zur Spize treibet, so hat die gelehrte Welt dennoch von Ihm was sonderbares zu hoffen, wenn Er seine Chymie, wie Er angefangen, ausführen, und, durch den Druck publiciren wird. Man siehet bereits, aus dem, Ihm nachgeschriebenen, und, wieder seinen Willen edirten Collegio Chymico, besonders, aus dem andern Theil daßelben, ein großes Licht, in die bißher finster Chymie erscheinen, und, die experimental Physiqve mit ihren Mechanischen Principiis vortrefflich darinn appliciret. 


\section{\$. 77.}

[Academischer Zustand zu Leiden.] Die Academie, welche dieser Stadt ein schönes Ansehen, und gute Consumption schafft, ist in sehr gutem Flor. Ich zehle unter ihre Commoda, daß Sie

1. unter einem Vernünfftigen, uninteressirten Regiement stehet, welches vor nichts so sehr alß das gemeine Beste bemühet ist. Ihre Curatores sind gelahrte, hocherfahrene Politici, und aufrichtige Patrioten, welche, jederzeit, die geschicktesten Leute /: vid. Martini Soermanns Academische Register, (welches eine kurze Historia Literaria von Leiden, und Utrecht ist) Leiden, 1704 in 8.므 :/ wo sie dieselbe gefunden, mit großen Salariis und Praemiis zur Academie gezogen, niemahls dagegen sich von Hudlern und Stumpern erkauffen laßen. Daher findet man, biß auf diese Stunde, die Professiones mit den geschicktesten Leuten besezt. Ich sehe keinen Professorem, der nicht seinem Metier völlig gewachßen sey. Wer sich, von selbigen, zum Aufnehmen der Academie appliciret, den wird das Salarium, nach und nach, vergrößert. So hat Albinus schon eine Zulage, und Boerhaven manche bekommen. Jüngst, ist diesem ein jährliches Capital, von 1000 fl. Holl. zur Correspondence, und freye Commision an die Indianischen Compagnien, accordirt worden. Am offentlichen Adminiculis Literarum läßet man nichts fehlen. Der Hortus Botanicus, Bibliotheqve, Observatorium, Auditorium Physico-Mathematicum, Theatrum Anatomicum, die Academischen Gebäude, sind alle, im aller schönsten, und nettesten Stande. Die guten Consilia, so ein jeder Professor zu seines Departaments Erweiterung giebet, finden Approbation und Nachdruck.

2. Die Professores haben nicht nur Geschicklichkeit, sondern auch rechte Lust und Trieb zu arbeiten. Ein jeder wartet seine Lectiones, laut dem Catalogo publico, fleißig ab. Man höret nicht, daß Jemand einer Läßigheit, oder eines unordentliches Lebens wegen, verlaßt sey. Man hält über den gemachten Ordnungen, und werden die Contravenienten zur gesezten Geld-Buße, von ihrem Collegio selbs forciret. Es sind alles Leute von guten Mitteln, und großen Ansehen, an diesem Orth; dazu sind ihre Salaria zu ihrem Unterhalt zulänglich; deßwegen ist ihnen verboten, unanständiger Weise, von Studenten Geld zu machen. Sie laßen ihnen die privat-Collegia zwar gut bezahlen; aber, wenn Ihnen Jemand davon gehet, werden sie ihn deßwegen nicht ehe, biß er promoviren will, anhalten. Die Buchführer caressiren die Professores sehr, und schaffen ihnen manchen Vortheil. Viel Professores sind in hiesigem Schöppen Stuhl, und ziehen auch von dennen ihre 
Emolumenta. Hr. Boerhaven, und D. Osterdyk Schacht ${ }^{93}$, sind mit im Magistrat.

3. Der Numerus Studiosorum ist zwar klein, aber auserlesen. Man siehet hin nicht, wie zu Halle, große Tische voll, unnützer auswärtiger Brodfreßer, die mit dem Unkraut grober Sitte das Academische Feld beziehen. Wer nicht Geld zu Leben hat, darf sich nicht hieher wagen; Und, wer hie ist, muß fleißig Studiren, damit er bald fortkomt, weil es viel Geld kostet; daher siehet man nicht Bursche offentlich debouchiren, oder Collegia negligiren. Die Frembden sind alle Leute von Jahren und Studiis, die sie von andern Universitäten mitgebracht. Wer hie Fundamenta lagen wollte, würde es verkehrt anfangen. Die vornehmen Prinzen, und vom Adel, so hie pro forma. studiren, haben ihre Hoffmeister, und Neben-Informatores, von welchen sie zwar aller Orthen proficiren, dabey aber nicht so retirè und, ohne Gefahr der Verführung, leben konnen. Die Plattergeister vergeßen hie das Stoltzieren und Großthun, weil sie es nicht lang aushalten können. Es ist auch gar umsonst, hie sich sehen laßen wollen, maßen sich keine Gelegenheit zu charmiren, noch zu conversiren findet; des Kleides, oder des Staats wegen, wird keinen höher aestimiret. Die Englländischen, und Holländischen Studenten, gehen mehrentheils in Schlaff-Röcken, ob wohl sie mehr Geld, alß die Teutschen haben, und, wenn sie Staat formiren, an Kostbarkeit die Teutschen übertreffen. Und diese machen die große Anzahl der Studenten aus; denn, Englländer, und Holländer, können keinen nähern und beßern Orth zum Studiren wehlen: Auch finden Medici nirgends in Teutschland beßere Anführung, zur Anatomie, Chirurgie, Botanic, Physiologie, alß hie, zu Leiden. Daher ist auch der Confluxus von dergl. Studiosis größer, alß anderwarts. Wer von dießen fleißig ist, und gute Fundamenta mitbringt, kan sich, im Jahr, von hie wohl expediren. Vor teutsche Juristen aber, und Theologos, taugt diese Academie gar nicht, weil außer denen wenigen, und übertheuren Collegiis Juridicis, des Schultings ${ }^{94}$, und Vitriarii ${ }^{95}$, welche ad inanem Theoriam führen, nichts practisches zu hören, noch zu erfahren ist. Was Theologi hie lesen, wird, so bald es geschloßen, offentlich ediret. Umb solcher Information willen, darf man nicht auf theuren und ungesunden Pflaster liegen. Aber, es ist der Mühe wohl

${ }^{93}$ Hermannus Oosterdijk Schacht (1672-1744) - niderlandzki medyk, profesor uniwersytetu w Lejdzie.

${ }^{94}$ Antonius Schultingh (1659-1734) - niderlandzki prawnik, profesor uniwersytetu w Lejdzie.

${ }^{95}$ Johann Jacob Vitriarius (1679-1745) - urodzony w Helwecji prawnik niderlandzki, profesor uniwersytetu w Lejdzie. 
werth, daß ein reisender Studiosus Theologiae, oder Juris, diesen Orth besuchet, und sich eine Weile in Literariis umbsiehet, ehe er von dannen eilet: Welches in wenigen Wochen, bey angenehmen SommerMonathen, geschehen kann. Andere Jahres-Zeit, ist den Teutschen sehr beschwerlich, weil das Land dem Scorbut, und häuffigen Fiebern sehr unterworffen ist, welche im Vorjahr, und Herbst, mit allerhand zufällen sich aüßern.

\section{§. 79.}

D. 11. 12. 13. Marty, waren auf der Academie 3. Doctor-Promotiones; die beyden ersten, in Medicina., publice ${ }^{96}$ : die 3.te in Jure, sub Camino. Der Doctorandus war Mons. Guil. Sautyn ${ }^{97}$, ein reicher Gast, von Amsterdam, aus vornehmer Famille: welche wir, bey leztern Frost, fleißig chaosen ryen, die aus Schritt-Schuhe lauffen gesehen haben. Selbiger ließ auf die Promotion viel gehen. Nach der Promotion, kahm er bey unsern Wirth, in den Tempel Salomonis, /: da wir, wegen Commoditè zu speisen angefangen :/ zu Tisch, und war, von der Fuß-Sohlen, biß am den Halß, mit breiten Silber beschlagen: Die Kleidung importirte mehr, alß manches Doctoris ganzes Capital. Unter der Mahlzeit, beachte der Pedell die Bulle, mit dem anhangenden großen Siegel, woran sich der Hr. Doctor über Tisch belustigte: Seine guten Freunde, und Tisch-Compagnons unterdeßen nicht etwas mit Ihm zu scherzen unterfiengen. Wegen die Nacht, umb 9. Uhr, war der Doctor-Schmauß angesezet, auf welchen unser Wirth die raresten Delicateßen zurichtete. Hie war wieder eine höltzerne verguldete Pastet vor 30. G. Holl. und, was nur neues und rares von Essen, am Wilpret, und Braten, zu erdancken war. Eine junge Ganß bezahlete der Koch mit 2. Ducaten, jede Phasan, 1. Ducaton. 1. Hasen, 6 G. Holl. Die Zurichtung war auf Personen wovor der Koch allein asbekommen.

\section{\$. 82.}

[Methoden in Stein-Schneiden.] D. 15. sahe Hr. ${ }^{\mathrm{n}}$ D. Albinum, in Lectionibus Chirurgicis, die operationes, circa calculos, et hernias,

${ }_{96} 11$ III dysputy De Pinguendinis corporis humani, sive panniculi adiposi veterum, hodie membranae cellulosae dicta, fabrica, bronił Johannes Grederic Hulsebusch z Osnabrugu. 12 III dysputy De Xvлолоíxб sive alimentorum in chylum mutatione bronił Johannes Burmann z Amsterdamu. Promotorem Burmanna był H. Boerhavve, a sam student zdał egzaminy dopuszczające 5 lutego, interpretując aforyzmy 16 i 17 z VI księgi Aforyzmów Hipokratesa. Boerhaave był także promotorem Hulsebuscha, a sam student omawiał aforyzmy 25 i 26 ze wspomnianej księgi. UBL, ASF-415, s. 280-281.

${ }^{97}$ Tytuł jego dysputy to De venia aetatis. 
demonstriren. Von der Lithotomie wiese Er IV. Methoden. 1.) die operatione altam, über dem Osse pubis. 2.) den apparatum magnum, wozu Catheter Sulcatus, ein bereites Meßer, 2. Conductores, mas et foemina, Ein Stylus ferreus, altera. parte, cochlearis instar, cavus, zum sondiren, ob mehr Steine, oder Grand verhanden, und eine Zange gehören. Diese operation geschiehet im Perinaeo, allwo der Urethra, unweit von dem cervice Vesicae, durchgeschnitten, und beyde, zur großern Marter des Patienten, also erweitert werden, daß ein, offtmahls hackigter Stein durchgerießen werden mag. 3.) der Apparatus minor, den Frater Jacob ${ }^{98}$, ohne Verstand, exerciret, Hr. Raw ${ }^{99}$ aber so perfectioniret, daß er billig vor die beste Methode bey alten Leuten gehalten wird. Der Schnitt geschiehet an der Seite, nahe am Exitu ani, und gehet in die Blase, über dem Cervice Vesicae, daß der Sphincter unversehret bleibet; hiezu sind der Catheter, ein Lithotomus, und, eine Zange zulänglich. 4.) Den 4. ${ }^{\text {te }}$ ist, Methodus Celsica, vor Kinder dienlich. Man suchet mit dem Finger durch den anum, den Stein, und druckt ihn nach vorn: nachmahls schneidet man über dem mercklichen Stein, und treibet mit dem Finger denselben durch die Wunde. Die Marqve einer glucklichen operation vom Steinschneiden, ist, wenn am Stein keine membranae kleben: waßwegen der operateur, wenn er den Stein mit der Zange heraus gezogen, nicht mit den Händen anfaßen muß, bevor man ihn ganz gesehen. Die übrigen Umbstände, sind, theil aus den Chirurgischen Autoribus bekandt, theil zu weitläufftih, hie zu erzehlen.

[Bruch-Schneiden.] Im Bruchschneiden, sind die Marcktschreyer offters zwar beherzt, und geübt, aber sie schneiden den Testiculum mit weg. Nehmlich, sie machen eine große Incision, untergraben den Funiculum Spermaticum, gesamt dem Sacco Peritonaei; nachdem sie die intestina, oder das omentum in den Leib zurück geschoben, reißen dem testiculum ex scroto, binden den Funiculum, und schneiden drunter alles gleich ab. Nach der chirurgia rationali, wird durch die geöfnete Haut, der Saccus Peritonaei, darinn der Tumor steckt, zerschnitten, die Wunde, entweder, mit dem Meßer in Conductore, oder, mit einem besondern Instrument, da ein subtiles Meßer im Conductore mista.

${ }^{98}$ Frère Jacques Beaulieu (Baulot) (1651-1720) - dominikanin, wędrowny litoto-

${ }^{99}$ Johannes Jacobus Rau (1668-1719) - niemiecki medyk aktywny w Niderlandach, profesor medycyny na uniwersytecie w Lejdzie. Jednym z jego uczniów był medyk Augusta II Mocnego Christian Heinrich Erndtel, który opisał jego metody operacyjne. Zob. Dziennik podróży uczonej Christiana Erndtela, lekarza przybocznego Augusta II, Warszawa 2018, passim. 
incurvo sich verbergen, und mit der Feder heben läßet, nach beyden Seiten verlänhert, nachmachls, wenn die Einrichtung des abhangenden Visceris geschiehet, zusammen gewickelt, und verheilet. Außer diesen, ist noch eine Method bekandt, mit dem puncto aureo. Nehmlich: Wenn man die Haut biß auf den Saccum Peritonaei durchschnitten, und den Bruch eingerichtet, wird ein guldener Dracht, umb den funiculum Spermaticum, und den, zusammen gedruckten Saccum geleget, und alß ein Ring zusammen gedrehet, dadurch die Gedärdme zurück gehalten werden. Dieses schafft viel Incommoda. Wenn die Vasa ein wenig anschrillen, sind die gefährlichsten Symptomata zu besorgen: der ring senckt sich herab, mit den Gedärmen, und drückt den Testiculum; die scharffen Ende stechen in die Haut, und machen Fisteln. Dieses verbeßern zwar einige, mit einem güldenen glatten Ring, der sich, wie ein Ohrgeheng, zuschließen läßt: Aber, sie heben dadurch nicht die ersten Incommoda. Die übrigen Ümbstände von dieser Materie, gehören nicht an diesen Orth.

[Anatomia Cerebri] An diesem Subjecto demonstriret auch Hr. Albinus, die Anatomiam cerebri, nach des Eustachii Tabulis, biß auf die origines nervorum, wozu Er des Vesslii Schemata recommendiret. In der Erklärung folget Er den Ridler ${ }^{100}$, Willis ${ }^{101}$, und Vieussen ${ }^{102}$, wiewohl er den leztern nicht lobet, weil er gar zu subtil und überflüßig accurat seyn will.

[Bücher-Auction in Haag.] Heute gieng auch die fürtreffliche Bücher-Auction eines ungenannten Besitzers, im Haag, an: davon der Catalogus beylieget. Darinne waren viel kostbare rare Bücher, und MSC ${ }^{\text {ta. }}$. die Zeit fiel mir zu kurz, vor unserer Abreise derselben beyzuwohnen, waßwegen aud einige Bücher nur Commission geben konte.

\section{S. 83.}

D. 16. hielte umb 10. Uhr, Morgens, unsere Landsmannschafft die privat-Communion, in der Lutherische Kirche, wozu wir neuliche Wache, den Hr. Johann Determeyer, alß andern Lutherischen Prediger, hatten erbitten laßen. [Plantae hiemales, in Horto Medico demonstratae.] Weil aber Hr. Boerhaven die Stünde vorher zur Demonstration der Plantarum hiemalium, angesezt, so gieng mit Hr. Schreibern, und Hr. Schwenck, zovor in den Hortum Medicum. Da denn die Bethe

${ }^{100}$ Humphrey Ridley (1653-1708) - medyk angielski, anatom.

101 Thomas Willis (1621-1675) - medyk angielski, anatom.

102 Raymond Vieussens (1635-1715) - medyk francuski, anatom. 
theils besäet und numeriret, theils, mit grünen Kräutern besezet, die Glaß-Häuser aber alle, vor der Sonne behangen waren. Hr. Boerhaven demonstriret die Kräuter, ohne Ordnung, wie Er sie in Tag-Register blühend annotiret. Ich will den abbreviirten Indicem plantarum demonstratum hieher sezen, die eigentlicher Bennenung ist im Indice altero, Boerhaven, da, wo ich ein $\Psi$. gezeichnet, vollständig zu lesen.

Genista Spartium, Thymilea, Philirea, Chelidonium minus, Epaticae plures Species, Ranunculus, Agaricus, Muscus, Lichen qvinqvefolium, Buxus, Myosotis, Gramen paniculatum, Corylus, Larix, Tussilago, Alsine, Bellis, Perasites, Laureola mas, Lenecio, Laureola folio deciduo, Lamium Sylvestre, Agrifolium, Herniaria, Primula veris. Herba Christi, seu Helleborus, Helleboroides, Alysson, Paronychia Veronica. foliis hederaceis, Hermodactyli, Cyclamen Colchicum, Hyacinthus, Mandragora, Dens canis, Narcisso Levcojum, Fragaria sterilis, Laurus Sylvestris, Tlaspidium, Jasminum Azoricum, Alaternoides, Lanecio Africanus, Cyclamen.

Von Genista Spartio mercket Hr. B. an, daß er sich zu Zäumen und Hecken ziehen ließe, welche wegen der gelben Blüthe ein artiges Ansehen haben. Die Hepatica muß im schattigen Orth stehen, unversezt, wenn der Sommer reiff werden soll. Dieser, wenn er auch nur von der einfachen Blumen Sorte gesamlet wird, giebt wunderliche varietates. Wenn die Pflanze offt versezet wird, verlieren diese, und dergleichen Blumen den Saamen, und bekommen dagegen viele Blätter, daher die Gärtner ihre wolle Blumen erzielen. Lichen, ist der Maß an den Mauren und Bäumen. Darinnen siehet man kleine Pyxides, aus welchen der Staub vom Wind verstäubet. Wo er aber auf einen naßen Orth, es sey, eine Mauer, oder ein Holtz, oder ein Stein hinfällt, da wachßet er aus. Vom Corylo sagt Hr. Boerhaven: Es wäre auf den Staminibus Julorum ein subtiler Staub, welcher vom Winde, in die, anderwerts, in den Ästen vorkommende Tubas falle, und daselbst zur Nuß anwachße. Der Baum wird daher Hermaphrodita genannt.

Laureola, folio deciduo, vulgo: Pfeffer-Bäumlein, bluhet in $\mathrm{Hr}$. Boerhavens Garten, mancherley Farbe. Alle aber tragen gifftige, und bißende Beerlein, welche die Gedärme inflammiren.

In Irrland sollen schöne Hecken von Lauretino zu sehen seyn.

Alsine, oder Hünerbiß, ist ein verächtliches Kraut, aber ein treffliches Antiscorbuticum, damit die lranckenden Vögel, so lang im Käfich geseßen, sich curiren. Bey denen übrigen Kräutern kahmen nur Nomenclaturae und Synonima vor. 


\section{Bibliografia}

Brzozowski S., Jacob Theodor Klein, iPSB - Internetowy Polski Słownik Biograficzny, https://www.ipsb.nina.gov.pl/a/biografia/jakub -teodor-klein?print.

Chachaj M., Podróże edukacyjne młodzieży z Prus Królewskich do Bolonii, Sieny i Perugii w XVI i XVII wieku, [w:] J. Wijaczka (red.), Prusy Ksiażęce i Prusy Królewskie w XVI-XVIII wieku, Kielce 1997.

Du Rieu W.N. (red.), Album studiosorum Academiae Lugduno Batavae 1575-1875, Apud Martinum Nijhoff 1875.

Dziennik podróży uczonej Christiana Erndtela, lekarza przybocznego Augusta II, wstęp K. Pękacka-Falkowska, tłum. i oprac. K. Pękacka-Falkowska, H. Bogusz, Warszawa 2018.

Ekkart R., Icones Leidenses. De portretten verzameling van de Rijksuniversiteit te Leiden, Leiden 1973.

Fisch J., Hollands Ruhm in Asien. François Valentijn Vision des niederländischen ImperiuMs. im 18. Jahrhundert, Wiesbaden 1986.

Gardiner J.E., Music in the Castle of Heaven: A Portrait of Johann Sebastian Bach, London 2013.

Hoftijzer P., Pallas Nostra Salus. Early modern Printer's Marks in Leiden as Expression of Professional and Personal Identity, [w:] A. Wolkenhauer, B.F. Scholz (red.), Typographorum Emblemata: The Printer's Mark in the Context of Early Modern Culture, Berlin 2018, DOI: https://doi.org/10.1515/9783110430271-008

Kenkel H., Studenten aus Ost- und Westpreußen an außerpreußischen Universitäten vor 1815, anhand der gedruckten Matrikeln, Hamburg 1981.

Klemme H.F., Kuehn M. (red.), The Bloomsbury Dictionary of Eighteenth-Century German Philosophers, London 2006.

Krause G., Gottsched und Flottwell, die begründer der Deutschen gesellschaft in Königsberg: Festschrift zur erinnerung an das 150 jährige bestehen der Königlichen deutschen gesellschaft zu Königsberg in Preussen, Königsberg 1893.

Księga wpisów uczniów Gimnazjum Gdańskiego. 1580-1814, oprac. Z. Nowak, P. Szafran, Warszawa 1974.

Kucharski A., Theatrum peregrinandi. Poznawcze aspekty staropolskich podróży w epoce późnego baroku, Toruń 2013.

Lindeboom G.A., Haller in Holland: het dagboek van Albrecht von Haller van zijn verblijf in Holland (1725-1727), Leiden 1979.

Nadolski B., Wyjazdy młodzieży gdańskiej na studia zagraniczne w XVII w., „Rocznik Gdański” 1965, R. 24. 
Paluchowski P., Jacob Theodor Klein, Gedanopedia, https://www.gedanopedia.pl/gdansk/?title=KLEIN_JACOB_THEODOR.

Pawlak M., Długokęcki W., Studia uniwersyteckie malborczyków do 1773 roku, Torun 2004.

Pawlak M.,Studia uniwersyteckie absolwentów Gimnazjum Elblaskiego w latach 1536-1772, „Zeszyty Naukowe Uniwersytetu Mikołaja Kopernika. Nauki Humanistyczno-Społeczne” 1967, t. 24.

Pawlak M., Studia uniwersyteckie grudziadzan w epoce staropolskiej, „Zeszyty Naukowe Wyższej Szkoły Pedagogicznej w Bydgoszczy. Studia Historyczne" 1993, t. 3.

Pawlak M., Studia uniwersyteckie młodzieży z Prus Królewskich w XVI-XVIII w., Toruń 1988.

Pawlak M., Wyjazdy młodzieży warmińskiej na studia uniwersyteckie w XVI-XVIII w., „Komunikaty Mazursko-Warmińskie” 1993, t. 3.

Pękacka-Falkowska K., Johann Philipp Breyne i jego ogrody: hortus vivus i hortus siccus, [w:] Historia - klimat - przyroda. Perspektywa antropocentryczna, Torú 2018.

Pękacka-Falkowska K., Matthias Ernst Boretius z Mazur i jego promocja doktorska $w$ Niderlandach: $z$ badań nad historia nauczania medycyny w XVIII wieku, [w:] A. Magowska, M. Owecki, K. Pękacka-Falkowska (red.), Wybrane problemy historii medycyny. W kreggu epistemologii i praktyki, Poznań 2020.

Pękacka-Falkowska K., The Medical Faculty at the University of Leiden and its Graduates from the Polish-Lithuanian Commonwealth. Some Introductory Remarks, „Bulletin der Polnischen Historischen Mission” 2020, nr 15, DOI: http://dx.doi.org/10.12775/BPMH.2020.004.

Philippi R. (red.), G. C. Pisanski’s Entwurf einer preußischen Literärgeschichte in vier Büchern, mit einer Notiz ueber den Autor und seine Buch, Königsberg 1886.

Pozzo R., Kant's Streit der Fakultaeten and Conditions in Koenigsberg, „History of Universities” 2000, vol. XVI, n. 2.

Preedek A., Ein Bibliotheksbesuche eines gelehrten Reisenden im Anfange des 18. Jhs., „Zentralblatt fur Bibliothekswesen” 1928, Jg. 45.

Preedek A., Ein vergessener Freund Gottscheds, w: Festschrift zur Zweihundertjahrfeier der Deutschen Gesellschaft in Leipzig 1727-1927, Leipzig 1927.

Salmonowicz S., Zwiazkki kulturalne Torunia i Gdańska z Królewcem w XVIII wieku, [w:] M. Bogucka, J. Kowecki (red.), Kultura polska a kultura europejska: prace ofiarowane Januszowi Tazbirowi w sześćdziesiata rocznice urodzin, Warszawa 1987. 
Schumann E., Geschichte der Naturforschenden Gesellschaft in Danzig 1743-1892: Festschrift zur Feier des 150 jährigen Bestehens der Naturforschenden Gesellschaft, Danzig 1893.

Siek B., Szarszewski A., Vitae medicorum Gedanensium Ludwiga von Hammena i Valentina Schlieffa, Gdańsk 2015.

Stackman U., Die Geschichte der chinesischen Bibliothek Tian Yi Ge vom 16. Jahrhundert bis in die Gegenwart, München 1990.

Talle A., «Ein Ort zu studieren, der seinen gleichen nicht hat»-Leipzig um 1730 in den Tagebuechern des Koenigsberger Professors Christian Gabriel Fischer, „Stadtgeschichte - Mitteilungen des Leipziger Geschichtsvereins. Jahrbuch 2008” 2008.

Thijsse L., Polska i Niderlandy: 1000 lat kontaktów, Zupthen 2003.

von Prantl C., Fischer, Christian Gabriel, w: Allgemeine Deutsche Biographie, hrsg. von der Historischen Kommission bei der Bayerischen Akademie der Wissenschaften, Bd. 7 Muenchen 1878.

Weichbrodt geb. v. Tiedemann D., Patrizier, Bürger, Einwohner der Freien und Hansestadt Danzig: in Stamm- und Namenstafeln vom 14.-18. Jahrhundert, Bd. 1, Eckernförde 1988.

Willes M., The curious world of Samuel Pepys and John Evelyn, London 2017.

Żołądź-Strzelczyk D., Kowalczyk M.E., Źródła do dziejów staropolskich podróży edukacyjnych, Wrocław 2018. 